\title{
Biological characteristics of a hydrothermal edifice mosaic community
}

\author{
Jozée Sarrazin*, S. Kim Juniper
}

GÉOTOP/Université du Québec à Montréal, Case Postale 8888, succursale Centre-Ville, Montréal (Québec) H3C 3P8, Canada

\begin{abstract}
This study defines the composition and biomass characteristics of 5 of 6 previously described faunal assemblages that form a mosaic community on hydrothermal sulfide edifices of the Juan de Fuca Ridge (northeast Pacific). Quantitative samples of each assemblage were acquired during 'ROPOS' Remote Operated Vehicle (ROV) dive programs in 1994 and 1996. Total abundance, and species richness, as well as wet and dry weights, were calculated for each assemblage, and sampled surface area was measured directly or from scaled images of sample scars. These data were used to compare species composition, richness and biomass of the distinct assemblages and to estimate total biomass of a sulfide edifice. In addition to major compositional differences, we observed an increase in density, biomass and species richness along a proposed successional sequence from the Paralvinella sulfincola (annelid polychaete) assemblage (Assemblage I) to the low-flow Ridgeia piscesae (vestimentifera) community (Assemblage V-LF). Biomass (dry weight without vestimentiferan tubes) of the different sampled assemblages ranged from $0.011 \mathrm{~kg} \mathrm{~m}^{-2}$ for Assemblage I to $4.68 \mathrm{~kg} \mathrm{~m}^{-2}$ for Assemblage V-LF and $2.33 \mathrm{~kg} \mathrm{~m}^{-2}$ for the rarer high-flow Ridgeia piscesae community (V-HF). Resulting quantitative information was used to refine a previous model of community succession. Comparisons with other marine ecosystems showed that the biomass of these and other hydrothermal assemblages dominated by symbiont-bearing organisms (vestimentifera, bivalvia) is similar to those found in the most productive photosynthetically based assemblages. Tubeworm growth and sulfide accretion greatly increase total surface area available to vent organisms, and may attenuate competition for space. The 3-dimensional habitat formed by Ridgeia piscesae tubes may influence species distribution and enhance species richness. The tube worm assemblages comprise the major and probably the most stable component of total edifice biomass. At one site, over a 4 yr period, there was substantial environmental change and major shifts in coverage by other assemblages but relatively little change in total coverage by $R$. piscesae. As a result total edifice biomass ( 219 to $251 \mathrm{~kg}$ dry weight) varied by only $16 \%$ over 1 to 3 yr intervals. Considerable quantitative ecological information can be derived from analyses of submersible-collected imagery, with sampling serving primarily as a ground truthing tool. Limitations of sampling and surface area determinations are considered.
\end{abstract}

KEY WORDS: Vent ecology - Biomass - Faunal succession - Sulfide edifice - Assemblage characteristics . Image analysis - Juan de Fuca Ridge $\cdot$ Ecological model · Marine ecosystem biomass

\section{INTRODUCTION}

Hydrothermal edifices are primarily formed by the accretion of sulfide minerals from hydrothermal fluids (Hannington et al. 1995). Organisms colonizing ac-

\footnotetext{
- Present Address: Woods Hole Oceanographic Institution, 360 Woods Hole Road, MS \#8, Mc Lean Lab 201, Woods Hole, Massachusetts 02 543-1539, USA

E-mail: jsarrazin@whoi.edu
}

tively venting edifices are heterogeneously distributed over complex structures that can be meters to $10 \mathrm{~s}$ of metres in height and $10 \mathrm{~s}$ to $100 \mathrm{~s}$ of $\mathrm{m}^{2}$ in surface area. Physical and chemical conditions often vary tremendously over the same structure, producing a mosaic of recurring faunal assemblages (Juniper \& Sarrazin 1995, Chevaldonné 1996, Sarrazin et al. 1997). Mineral accretion, changes in fluid flow and catastrophic perturbations have been observed to modify species distribution and mosaic pattern at sub-annual time scales (Tunnicliffe et al. 
1985, Tunnicliffe \& Juniper 1990, Chevaldonné et al. 1991, Tunnicliffe 1991, Sarrazin et al, 1997). Biological processes such as succession, predation and competition are also believed to influence the spatio-temporal distribution of vent species and community structure, within the constraints imposed by environmental factors (Hessler et al. 1988, Tunnicliffe \& Juniper 1990, Juniper \& Sarrazin 1995, Sarrazin et al. 1997). Several publications discuss faunal succession in relation to the life cycle of sulfide edifices, but this phenomenon is understood only in a descriptive sense (Fustec et al. 1988, Tunnicliffe \& Juniper 1990, Sarrazin et al. 1997). Critical examination of successional processes on hydrothermal edifices has been hindered by a lack of basic quantitative information on the different components of the faunal mosaic. This in turn can be attributed to the difficulties inherent in using submersibles to obtain quantitative samples from hard substrata.

Six distinct faunal assemblages were recently described from video and photographic imagery of a sulfide edifice of the Juan de Fuca Ridge (Sarrazin et al. 1997). Three assemblages (Assemblages IV-VI) contained vestimentifera (Ridgeia piscesae) whose tubes serve as substrata for other species and are differentiated by worm tube lengths and relative species abundance. Two assemblages (Assemblages I and II) appeared to contain only alvinellid polychaetes (Paralvinella palmiformis and Paralvinella sulfincola). These 6 faunal assemblages formed a mosaic of decimeter- to meter-scale patches covering $>90 \%$ of the edifice surface, and similar mosaic communities are common on hydrothermal edifices throughout the northeast Pacific. Observation of inter-annual shifts in mosaic pattern led Sarrazin et al. (1997) to propose a model for faunal succession on sulfide edifices where community transitions are driven by fluid flow variations and biological processes operating at sub-annual time scales. Because species assemblages were first identified only from imagery, small organisms and those hidden within the 'understory' of tube worm aggregations were not included in earlier descriptions. We report here on analysis of quantitative samples that define the composition and biomass characteristics of the distinct assemblages that make up a sulfide edifice mosaic community in the northeast Pacific. Resulting quantitative information was then used to revise our previous model of community succession (Sarrazin et al. 1997) to include biomass and species richness, and to consider biomass distribution and mosaic dynamics at the scale of a large $\left(>200 \mathrm{~m}^{2}\right.$ surface area) hydrothermal edifice. Also, the 2 forms of tube worm assemblages previously identified (Sarrazin et al. 1997) are now separately considered in the proposed succession model.

\section{MATERIALS AND METHODS}

Study site. All samples were collected from active sulfide structures located in the center of the Main Endeavour Field on the Endeavour Segment (Juan de
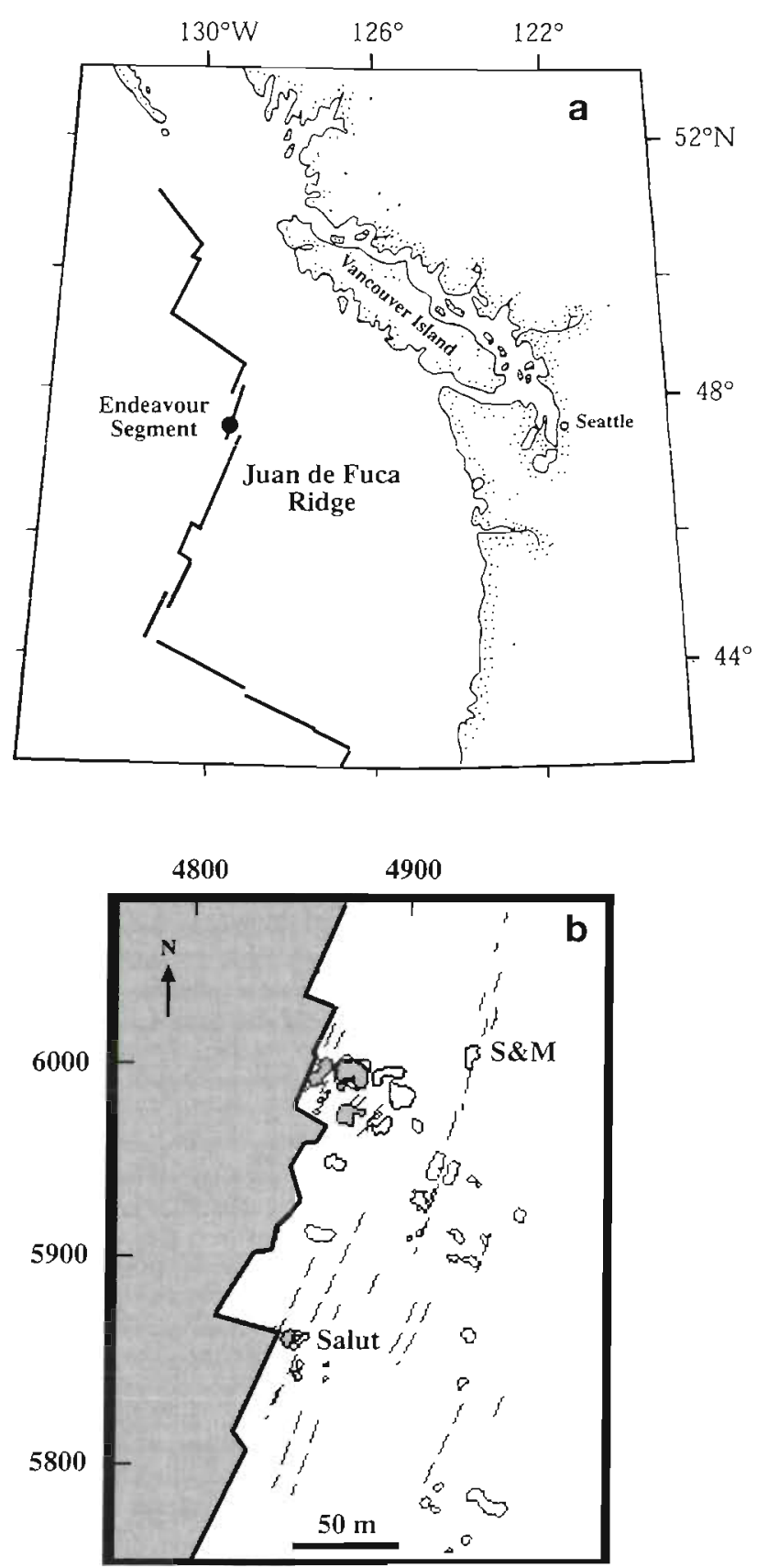

Fig. 1. (a) General location map of the Endeavour Segment, Juan de Fuca Ridge in the northeast Pacific Ocean. (b) The Smoke and Mirrors (S\&M) sulfide structure $\left(47^{\circ} 57^{\prime} \mathrm{N}\right.$, $\left.129^{\circ} 08^{\prime} \mathrm{W}\right)$ and the Salut edifice $\left(47^{\circ} 56^{\prime} \mathrm{N}, 129^{\circ} 05^{\prime} \mathrm{W}\right)$ are located in the centre of the Endeavour active hydrothermal vent field (map refers to Alvin navigation coordinates in meters). Modified from Sarrazin et al. (1997) 
Fuca Ridge, northeast Pacific), at a depth of $\sim 2200 \mathrm{~m}$ (Tivey \& Delaney 1986, Delaney et al. 1992) (Fig. 1a). Assemblages I, III, IV and V (Sarrazin et al. 1997) were sampled on the Smoke and Mirrors (S\&M) edifice (Fig. 1b). Assemblage II was inaccessible on S\&M and was sampled on the nearby Salut edifice, $150 \mathrm{~m}$ to the southwest (Fig. 1b). S\&M has been the focus of an extensive biological and geological study, where the distribution of fluid flow, geological features and 6 identified faunal assemblages (I to VI) were mapped and followed over a 4 yr period (1991, 1994 \& 1995) (Sarrazin et al 1997). Salut is a smaller, highly active edifice with abundant horizontal flanges that are typical of sulfide structures on Endeavour Segment (Delaney et al. 1992, Robigou et al. 1993, Hannington et al. 1995).

Sample collection. Samples were collected during 1994 and 1996 cruises to the Endeavour Segment using the Remotely Operated Vehicle (ROV) 'ROPOS'. The vehicle is equipped with 2 manipulator arms on which different sampling tools can be fitted (Shepherd \& Juniper 1997, see also www.ropos.com). Two of these tools were used to collect faunal samples. The 'Pacman' grab (maximum collection area $\sim 0.045 \mathrm{~m}^{2}$ ) was used to remove intact clumps from the denser assemblages (III, IV, V) while a suction sampler was used for collection of low-density Assemblage I. Pacman samples were placed in an aluminum sample tray or a Lexan 'biobox' before transfer to the surface. Both sample containers were closed hydraulically immediately after collection. Assemblage II, also low density, was collected by removing an entire small flange from the side of the Salut edifice. The ROPOS 7 -function manipulator was used to break off the flange into the opened sample tray that was then closed by retraction beneath the vehicle.

Colour video imagery was used to select sampling locations that were accessible and representative of the different assemblages. The low-flow Assemblage $V$ was sampled during the 1994 BioROPOS cruise (Juniper et al. 1994), whereas 4 different dives were dedicated to sampling all other assemblages during the REVEL 1996 cruise (Juniper et al. 1996). Sampling difficulties and time limitations prevented collection of all assemblages on the same edifice during the same year. Only 1 quantitative sample of each assemblage $(\mathrm{n}=1)$ was obtained. The lack of concordance between sampling methods and the absence of replicates for assemblages limit the interpretation of our results. Among the 6 assemblages described in Sarrazin et al. (1997), only assembläge VI (senescent tube worms) was not successfully sampled.

Onboard ship, samples were partially sorted and fixed in buffered seawater formalin $(10 \%)$. High-flow Assemblage $V$ was transferred to ethanol for shipment.
Table 1 Dominant species or faunal groups in the sampled assemblages

\begin{tabular}{|ll|}
\hline Species & Order or class: phylum \\
\hline Mega/macrofauna & \\
Paralvinella sulfincola & Terebellida: Annelida \\
Paralvinella palmiformis & Terebellida: Annelida \\
Ridgeia piscesae & Vestimentifera: Pogonophora \\
Polynoids & Phyllodocida: Annelida \\
Lepetodrilus fucensis & Vetigastropoda: Mollusca \\
Depressigyra globulus & Caenogastropoda: Mollusca \\
Buccinum cf viridum & Caenogastropoda: Mollusca \\
Provanna variabilis & Caenogastropoda: Mollusca \\
Pycnogonids & Pycnogonida: Arthropoda \\
& \\
Macro/meiofauna & \\
Amphisamytha galapagensis & Terebellida: Annelida \\
Nicomache venticola & Capitellida: Annelida \\
Hesiospina vestimentifera & Phyllodocida: Annelida \\
Helicoradomenia juani & Solenogaster: Mollusca \\
Copepods & Crustacea: Arthropoda \\
Ostracods & Crustacea: Arthropoda \\
& \\
\hline
\end{tabular}

A list of the different species sampled and their taxonomic affiliation is provided in Table 1. Morphometric measurements (length and width) were made on each individual mega/macrofaunal organism. Dry and wet weights were determined for up to 500 individuals per species per assemblage (range 13 to 501). For the remainder, weights were estimated from linear correlation between wet and dry weight versus morphometric data $(p<0.05)$. Total abundance, relative species density, species richness, and wet and dry weights were calculated for each assemblage. Since some species were not identified, species richness should only be considered as a semi-quantitative index because it included faunal groups harboring more than one species (e.g. pycnogonids). For sub-macroscopic organisms (meiofauna and small macrofauna), only abundance was determined for larger species while only presence/absence was noted for smaller species (copepods, ostracods)

Sample surface area estimation. Following collection with the Pacman or suction samplers, the cleared area was imaged with the 3-CCD (Charge-Coupled Device) colour video camera. Two parallel lasers $(10 \mathrm{~cm}$ separation) mounted on the camera provided scale for surface area determinations. To estimate the surface area sampled, video images of the sample scars were captured to disk from recordings. Three replicate views of each sampling site were analyzed. Quantitative 2-D surface analyses for each assemblage were performed on the video images using IPLab Spectrum ${ }^{(B)}$ image analysis software (Grehan \& Juniper 1996, Sarrazin et al. 1997). On screen, scale was set in images from visible laser points, the denuded surface was 
digitized by outlining, and area was calculated using the Spectrum ${ }^{3}$ segment measurement function. Areal determinations were performed in triplicate for each image to reduce errors resulting from on-screen tracing (Sarrazin et al. 1997). Total sampled area was then calculated in square metres as the mean of 9 ( 3 separate images $\times 3$ replicate measurements) determinations for each distinct assemblage (see Table 4). While sampled surfaces had to be generally flat in order for sampling to succeed, this 2-D determination did not account for relief and therefore underestimated the real surface colonized by the organisms. The flange surface area estimation was done by direct measurement on board the ship.

Morphometric measurements. Total body length for the polychaete Paralvinella sulfincola (Assemblages I and II) was a good indicator of both wet and dry weights while, for Paralvinella palmiformis, several morphometric measurements such as maximum worm width, total length (Assemblages II, III and IV) and diametre under gills (Assemblage III) were highly correlated with wet and dry weights $(p<0.05)$. While several authors have proposed the width at the 7 th setigerous segment as the best representative measurement for terebellomorph polychaetes (review by Chevaldonné 1996), we used measurements that were visible in video image. We are presently developing techniques for making biomass determinations from imagery, by examining relationships between visible morphometric features and body weight. Body wet or dry weights for lots of 50 limpets (Lepetodrilus fucensis) were estimated from total displaced volume and from total wet and dry weights (including tissue and shells; Assemblages III \& V) $(p<0.05)$. For lots of 50 snails (Depressigyra globulus), total wet and dry weights (including tissue and shells; Assemblage III) were used to estimate body weights $(p<0.05)$. Polynoid total length was correlated with wet and dry weight (Assemblage III) $(p<0.05)$. Finally, for the vestimentiferan Ridgeia piscesae, tube and worm lengths were used to estimate wet and dry weights (Assemblages IV and $V)(p<0.05)$. Tube and worm wet weights were also used to estimate dry weights (Assemblage V). For comparison with previous studies, which often include tubes in their biomass estimations, total biomass with and without vestimentiferan organic tubes is presented.

Density and biomass. Relative species density was directly calculated from the total number of individuals sampled from the estimated 2-D surface areas. Wet and dry weights of each individual were either directly measured or extrapolated from established linear relationships with morphometric measurements. Regressions between wet or dry weight and morphometric measurements, used to interpolate unmeasured weights for principal species and groups in the 5 distinct assemblages, were all statistically significant $(\mathrm{p}<0.05)$. Biomass of distinct species and total assemblage biomass were then calculated for the 5 sampled assemblages (including both low- and high-flow Assemblage $V$ ).

\section{RESULTS}

\section{Assemblage characteristics - composition}

Assemblage I. The alvinellid polychaete Paralvinella sulfincola and the limpet Lepetodrilus fucensis were the most abundant mega/macrofaunal species in this sample (Table 2). The limpets were contaminants introduced from an adjacent Assemblage III during sampling. In all video and still imagery, Assemblage I is composed of $P$. sulfincola populations, with mobile polynoid polychaetes often moving through and grazing. $P$. sulfincola contributed more than $71 \%$ of the total biomass (wet weight) while less abundant polynoid polychaetes contributed $-23 \%$ of the biomass. The relative contributions of the 3 species to total dry weight biomass were similar (Table 2). Sub-macroscopic species in the sample were dominated by the polychaete Amphisamytha galapagensis, by the aplacophoran Helicoradomenia juani and by unidentified gastropod species. Copepods were present in small numbers (Table 3).

Assemblage II. Alvinellid polychaetes (Paralvinella palmiformis, Paralvinella sulfincola and unidentified Paralvinella spp.) dominated Assemblage II, comprising more than $85 \%$ of the biomass (for both wet and dry weights; Table 2). Lower numbers of polynoids and gastropods (Lepetodrilus fucensis and Depressigyra globulus) were also present (Table 2). No sub-macroscopic organisms were found in the sample (Table 3 ).

Assemblage III. Paralvinella palmiformis and Lepetodrilus fucensis contributed to more than $70 \%$ of the biomass of Assemblage III (for both wet and dry weights; Table 2). High densities of the small snail Depressigyra globulus were also observed but their contribution to total biomass was low ( 9 to $11 \%)$. Two other species of snails (Provanna variabilis and Buccinum cf. viridum) and polynoid polychaetes were present in small numbers. The few polynoids and $P$. variabilis were used for isotope measurements (C.R. Fisher Laboratory), and so were not included in biomass estimates (Table 2). Amphisamytha galapagensis densities were higher than in Assemblage I (Table 3). Submacroscopic polychaetes, copepods and ostracods were also observed.

Assemblage IV. The vestimentiferan Ridgeia piscesae and the limpet Lepetodrilus fucensis dominated 
Table 2. Mega/macrofaunal species composition of 5 distinct assemblages of northeast Pacific high-temperature vent sulfide structures, including low-flow and high-flow forms of Assemblage V. Density and wet and dry biomass as well as the relative contribution (\%) of each species to the total biomass are given. Assemblages with vestimentiferan include both wet and dry weights with or without the presence of tubes (values excluding tubes are shown in parentheses). Area SDs are I $( \pm 0.0007)$, II $( \pm 0.0000)$, III $( \pm 0.0042)$, IV $( \pm 0.0023), \mathrm{V}-\mathrm{LF}( \pm 0.0042), \mathrm{V}-\mathrm{HF}(0.0089)$. SDs apply to all data related to area

\begin{tabular}{|c|c|c|c|c|c|}
\hline Assemblages & $\begin{array}{l}\text { Density } \\
\left(\text { ind } \mathrm{m}^{-2} \text { ) }\right.\end{array}$ & $\begin{array}{c}\text { Biomass wet weight } \\
\qquad\left(\mathrm{g} \mathrm{m}^{-2}\right)\end{array}$ & $\begin{array}{c}\text { Biomass dry weight } \\
\left(\mathrm{g} \mathrm{m}^{-2}\right)\end{array}$ & $\%$ wet weight & $\%$ dry weight \\
\hline \multicolumn{6}{|l|}{ I } \\
\hline Paralvinella sulfincola & 322 & 37.42 & 8.39 & 71.8 & 73.2 \\
\hline Polynoids & 25 & 12.30 & 2.62 & 23.6 & 22.9 \\
\hline Lepetodrilus fucensis & 305 & 2.39 & 0.45 & 4.6 & 3.9 \\
\hline \multicolumn{6}{|l|}{ II } \\
\hline Paralvinella palmiformis & 3602 & 218.21 & 41.56 & 26.7 & 26.4 \\
\hline Paralvinella sulfincola & 3380 & 397.01 & 71.48 & 48.6 & 45.4 \\
\hline Alvinellids & 3167 & 121.28 & 22.87 & 14.8 & 14.5 \\
\hline Polynoids & 130 & 62.70 & 13.37 & 7.7 & 8.5 \\
\hline Lepetodrilus fucensis & 944 & 14.95 & 7.03 & 1.8 & 4.5 \\
\hline Depressigyra globulus & 630 & 3.42 & 1.14 & 0.4 & 0.7 \\
\hline \multicolumn{6}{|l|}{ III } \\
\hline Paralvinella palmiformis & 6710 & 717.00 & 158.01 & 57.1 & 53.0 \\
\hline Paralvinella sulfincola & 774 & 102.54 & 22.43 & 8.2 & 7.5 \\
\hline Polynoids & 97 & -- & - & - & \\
\hline Provanna variabilis & 32 & -- & - & - & \\
\hline Lepetodrilus fucensis & 37129 & 215.54 & 57.44 & 17.2 & 19.3 \\
\hline Depressigyra globulus & 20903 & 122.45 & 34.23 & 9.7 & 11.5 \\
\hline Buccinum cf vindum & 65 & 99.07 & 25.88 & 7.9 & 8.7 \\
\hline \multicolumn{6}{|l|}{ IV } \\
\hline Ridgeia piscesae & 10310 & $193.14(134.11)$ & $65.82\{28.9\}$ & $41.7(33.2)$ & $48.5(29.2)$ \\
\hline Paralvinella palmiformis & 2241 & 32.94 & 7.88 & $7.1(8.2)$ & $5.8(8.0)$ \\
\hline Paralvinella sulfincola & 276 & 20.22 & 4.88 & $4.4(5.0)$ & $3.6(4.9)$ \\
\hline Provanna variabilis & 379 & 6.36 & 2.09 & $1.4(1.6)$ & $1.5(2.1)$ \\
\hline Lepetodrilus fucensis & 62931 & 194.28 & 49.76 & $42.0(48.1)$ & $36.6(50.3)$ \\
\hline Depressigyra globulus & 6310 & 15.20 & 5.29 & $3.3(3.8)$ & $3.9(5.4)$ \\
\hline Pycnogonids & 34 & 0.90 & 0.11 & $0.2(0.2)$ & $0.08(0.1)$ \\
\hline \multicolumn{6}{|l|}{ V-low flow } \\
\hline Ridgeia piscesae & 66903 & $12260.5(5780.97)$ & $2908.55(2087.7)$ & $58.6(40.1)$ & $52.9(44.6)$ \\
\hline Paralvinella palmiformis & 2000 & 180.81 & 29.17 & $0.9(1.3)$ & $0.5(0.6)$ \\
\hline Paralvinella sulfincola & 97 & 5.81 & 1.5 & $0.03(0.04)$ & $0.03(0.03)$ \\
\hline Provanna variabilis & 4259 & 71.41 & 23.42 & $0.3(0.5)$ & $0.4(0.5)$ \\
\hline Lepetodrilus fucensis & 108226 & 7850.58 & 2417.00 & $37.5(54.4)$ & $44.0(51.7)$ \\
\hline Depressigyra globulus & 64839 & 38.46 & 13.39 & $0.2(0.3)$ & $0.2(0.3)$ \\
\hline Polynoids & 1001 & 483.65 & 103.13 & $2.3(3.4)$ & $1.9(2.2)$ \\
\hline Pycnogonids & 452 & 16.32 & 3.06 & $0.08(0.11)$ & $0.06(0.07)$ \\
\hline \multicolumn{6}{|l|}{ V-high flow } \\
\hline Ridgeia piscesae & 14036 & $14560.93(11185.03)$ & $2342.98(1656.6)$ & $72.8(67.3)$ & $77.7(71.1)$ \\
\hline Paralvinella palmiformis & 11691 & 4885.39 & 599.20 & $24.4(29.4)$ & $19.9(25.7)$ \\
\hline Paralvinella sulfincola & 3818 & 528.31 & 70.73 & $2.6(3.2)$ & $2.3(3.0)$ \\
\hline Polynoids & 55 & 18.23 & 1.95 & $0.09(0.1)$ & $0.06(0.08)$ \\
\hline
\end{tabular}

Table 3. Relative densities of macro/meiofaunal species (ind. $\mathrm{m}^{-2}$ ) in 5 distinct assemblages of northeast Pacific high-temperature vent sulfide structures, including low-and high-flow forms of assemblage V. For copepods and ostracods only presence/absence is indicated

\begin{tabular}{|c|c|c|c|c|c|c|c|c|}
\hline \multirow{2}{*}{$\begin{array}{l}\text { Assem- } \\
\text { blages }\end{array}$} & \multicolumn{4}{|c|}{$\longrightarrow$ Polychaetes $\longrightarrow$} & \multirow{2}{*}{$\begin{array}{c}\text { Molluscs } \\
\text { Helicoradomenia } \\
\text { juani }\end{array}$} & \multirow{2}{*}{ Gastropods } & \multirow{2}{*}{$\begin{array}{l}\text { Others } \\
\text { Copepods }\end{array}$} & \multirow{2}{*}{ Ostracods } \\
\hline & $\begin{array}{c}\text { Amphisamytha } \\
\text { galapagensis }\end{array}$ & $\begin{array}{l}\text { Nicomache } \\
\text { venticola }\end{array}$ & $\begin{array}{c}\text { Hesiospina } \\
\text { vestimentifera }\end{array}$ & Others & & & & \\
\hline I & 212 & - & - & - & 59 & 16 & Present & - \\
\hline II & - & - & - & - & - & - & - & - \\
\hline III & 548 & - & - & 97 & - & - & Present & Present \\
\hline IV & 9276 & 34 & - & - & 966 & - & Present & Present \\
\hline V-LF & 65 & - & 129 & - & 2032 & - & - & - \\
\hline $\mathrm{V}-\mathrm{HF}$ & - & - & - & - & - & - & Present & - \\
\hline
\end{tabular}


Assemblage IV with a $>80 \%$ contribution to total wet weight biomass (Table 2). $R$. piscesae and L. fucensis also dominated dry weight biomass. The polychaetes Paralvinella palmiformis and Paralvinella sulfincola, and the snails Provanna variabilis and Depressigyra globulus, as well as pycnogonids, were present in much smaller densities, contributing $\approx 20 \%$ to total biomass (Table 2). Assemblage IV included 5 sub-macroscopic species or groups. Amphisamytha galapagensis reached its highest density and the capitellid polychaete Nicomache venticola was found only in this assemblage (Table 3 ).

Assemblage V. Two forms of Assemblage $V$ were identified in video imagery (Sarrazin et al. 1997) and both were sampled. Visible intensity of hydrothermal flow as well as Ridgeia piscesae phenotype differentiate the 2 assemblages. Low-flow Assemblage V(V-LF) is composed of long vestimentifera with poorly developed branchial filaments while high-flow Assemblage $\mathrm{V}(\mathrm{V}-\mathrm{HF})$ vestimentifera have wide white tubes and a prominent, feathery branchial plume (Southward et al. 1995).

Low flow: Ridgeia piscesae and Lepetodrilus fucensis dominated the biomass (for both wet and dry weights) while $L$. fucensis had the highest density (Table 2). The contribution of $L$. fucensis to total biomass increases to over $50 \%$ when vestimentiferan tubes are removed from calculations. The small snails Depressigyra globulus and Provanna variabilis were relatively abundant but added little to total biomass
(Table 2). Polynoids and pycnogonids were more numerous than in other assemblages. The sub-macroscopic macro/meiofauna was composed of 3 species, Amphisamytha galapagensis, Hesiospina vestimentifera and Helicoradomenia juani, and largely dominated by the aplacophoran $H$. juani (Table 3 ).

High flow: Only $4 \mathrm{mega} / \mathrm{macrofaunal}$ species were present in this form of Assemblage $V$, which was dominated by the vestimentiferan Ridgeia piscesae (for both wet and dry weights; Table 2). Paralvinella palmiformis and Paralvinella sulfincola were more abundant than they were in low-flow Assemblage V. Gastropods were absent, and there were few polynoids. Copepods were the only sub-macroscopic animals found in this assemblage (Table 3 ).

\section{Assemblage characteristics-species richness, density and biomass}

Assemblages III, IV and Assemblage V-LF had the highest species richness indices ( $\geq 11$ ) (Fig. 2a). Assemblage V-LF had the highest density and biomass; Assemblage I had the lowest (Table 4, Fig. 2b-d). Data show a density increase from Assemblage I through Assemblage V-LF, but lower density in Assemblage VHF (Table 4, Fig. 2b). Biomass (for both wet and dry weights) was lowest in Assemblage I, at intermediate levels in Assemblages II-IV and very high in both forms of Assemblage $V$ (Table 4, Fig. 2C,d). There is a
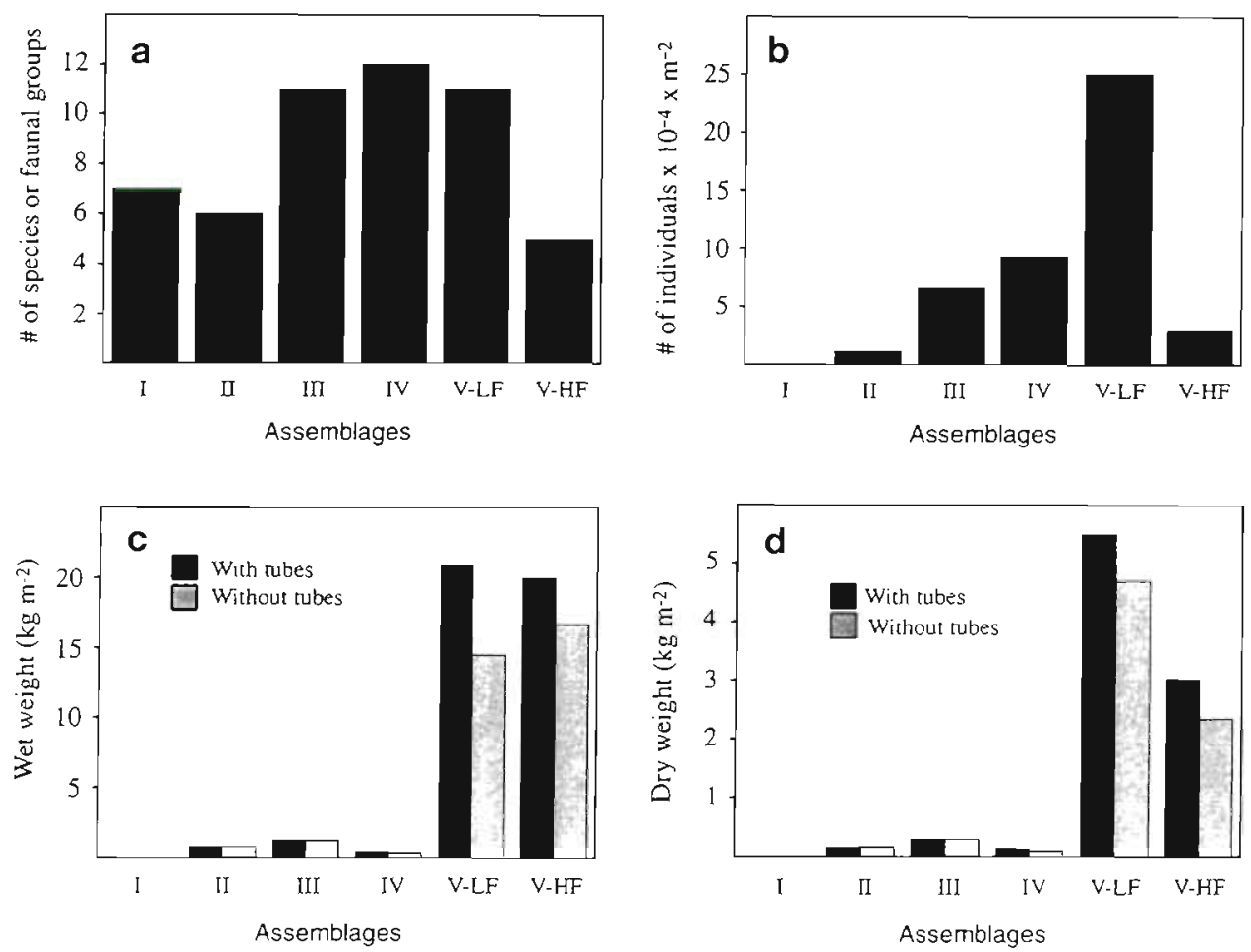

Fig. 2. (a) Species richness index numbers of individuals or faunal groups) of 5 distinct Assemblages (I to V), including the low-flow and high-flow forms of Assemlage $V$. (b) Total faunal density (ind. $\mathrm{m}^{-2}$ ) of 5 distinct assemblages (I to $\mathrm{V}$ ), including low-flow and high-flow forms of Assemblage $\mathrm{V}$. (c) Total wet biomass $(\mathrm{kg}$ $\mathrm{m}^{-2}$ ) with and without vestimentiferan tubes of 5 distinct assemblages ( $\mathrm{I}$ to $\mathrm{V}$ ) including low-flow and highflow forms of Assemblage $\mathrm{V}$. (d) Total dry biomass $(\mathrm{kg}$ $\mathrm{m}^{-2}$ ) with and without vestimentiferan tubes of 5 distinct assemblages (I to $\mathrm{V}$ ) including low-flow and high-flow forms of Assemblage $V$ 
Table 4. Summary of analyses of faunal samples from 5 distinct assemblages of northeast Pacific high-temperature vent sulfide structures, including the low-flow and high-flow forms of Assemblage $\mathrm{V}$. Richness index includes either individual species richness or faunal groups that may include more than 1 species. Assemblages with vestimentiferans include both wet and dry weights with or without the presence of tubes (values excluding tubes are given in parentheses). Area SDs, apply to all data related to area

\begin{tabular}{|c|c|c|c|c|c|c|c|c|}
\hline $\begin{array}{l}\text { Assem- } \\
\text { blage }\end{array}$ & $\begin{array}{c}\text { Total } \\
\text { organism } \\
\text { abundance }\end{array}$ & $\begin{array}{l}\text { Richness } \\
\text { index }\end{array}$ & $\begin{array}{l}\text { Wet weight } \\
\qquad(g)\end{array}$ & $\begin{array}{c}\text { Dry weight } \\
(g)\end{array}$ & $\begin{array}{l}\text { Area } \pm S D \\
\qquad\left(\mathrm{~m}^{2}\right)\end{array}$ & $\begin{array}{c}\text { Total } \\
\text { density } \\
\text { (ind. } \mathrm{m}^{-2} \text { ) }\end{array}$ & $\begin{array}{c}\text { Biomass } \\
\text { wet weight } \\
\left(\mathrm{kg} \mathrm{m} \mathrm{m}^{-2}\right)\end{array}$ & $\begin{array}{c}\text { Biomass } \\
\text { dry weight } \\
\left(\mathrm{kg} \mathrm{m} \mathrm{m}^{-2}\right)\end{array}$ \\
\hline I & 111 & 7 & 6.15 & 1.35 & $0.118^{\mathrm{d}} \pm 0.0007$ & 941 & 0.052 & 0.011 \\
\hline II & 1280 & 6 & 88.30 & 17.00 & $0.108^{b} \pm 0.0000$ & 11852 & 0.818 & 0.157 \\
\hline III & 2059 & 11 & 38.95 & 9.24 & $0.031^{c} \pm 0.0042$ & 66419 & 1.257 & 0.298 \\
\hline IV & 2694 & 12 & $13.43(11.72)$ & $3.94 \quad(2.87)$ & $0.029^{c} \pm 0.002$ & 92896 & $0.463(0.404)$ & $0.136 \quad(0.099)$ \\
\hline$V-L F$ & 7750 & 11 & $648.13(447.27)$ & $170.48(145.03)$ & $0.031^{c} \pm 0.0042$ & 250000 & $20.908(14.43)$ & $5.50(4.68)$ \\
\hline $\mathrm{V}-\mathrm{HF}$ & 1628 & 5 & $1099.61 \quad(913.93)$ & $165.82(128.07)$ & $0.055^{c} \pm 0.0089$ & 29600 & $19.993(16.62)$ & $3.01 \quad(2.33)$ \\
\hline
\end{tabular}

significant correlation between biomass where vestimentiferan tubes are included and biomass without the tubes $\left(r^{2}=0.95\right.$ for wet weight, $r^{2}=0.98$ for dry weight, $p<0.05)$. Despite a relatively low faunal density, the wet weight biomass of Assemblage V-HF was similar to that of Assemblage V-LF (Table 4, Fig. 2c) while dry weight biomass was half as much. The wet weight:dry weight ratio was more elevated for all species of the high-flow assemblage. For example, vestimentifera from the high-flow sample had an $84 \%$ water content compared to $76 \%$ for the low-flow vestimentifera. The transfer of Assemblage V-HF from formalin to alcohol for transportation could explain the observed difference in water content. In a study of the effect of chemical preservatives on sample dry weights, Campbell \& ChowFraser (1995) demonstrated that storing samples in ethanol yields lower dry weights than does storage in formalin. However, the large contribution of dense (69\% water) limpet tissue to total biomass of Assemblage V-LF also contributed to the overall observed wet weight:dry weight differences. Limpets were absent from the Assemblage V-HF sample.

Sarrazin et al. (1997) proposed a progressive succession from Assemblage I to Assemblage VI. Figs. 3 \& 4 compare density and biomass of the 6 most significant species or faunal groups across the 5 sampled assemblages. These data provide evidence for a progressive transition from Assemblage I through to Assemblage V-LF, and illustrate the contrasting nature of the 2 forms of Assemblage V. Ridgeia piscesae was absent from Assemblages I-III and most dense in Assemblage V-LF (Fig. 3a), while its wet biomass was highest in Assemblage V-HF (Fig. 4a). Density (Fig. 3b) and biomass (Fig. 4b) of Paralvinella palmiformis were highest in Assemblage V-HF, and rather elevated in Assemblage III. P. sulfincold also had its highest density and biomass (wet wt) in Assemblage V-HF and values were only slightly lower in Assemblage II (Figs. $3 \& 4$ c). All gastropods were pooled together to evaluate their distribution among the 5 assemblages. This included Lepetodrilus fucensis, Depressigyra globulus, Provanna variabilis and Buccinum cf. viridum. Gastropod density increased from Assemblage II to Assemblage V-LF (Fig. 3d), where their biomass (both wet and dry wt) was maximal (Fig. 4d). Mobile polynoids were present in all assemblages except Assemblage IV (Fig. 3e). Their density and biomass (both wet and dry wt) were highest in Assemblage V-LF (Figs. 3 \& 4e). Pycnogonids were only observed in 2 Assemblages (IV and V) and were most abundant in Assemblage V-L.F (Figs. 3 \& 4f).

\section{Length class frequencies}

For all 5 assemblages, we examined length class frequencies of the 3 most common worm species, Paralvinella sulfincola, Paralvinella palmiformis and Ridgeia piscesae, for evidence of recruitment and growth patterns (Fig. 5). P. sulfincola polychaetes were present in all samples, with smaller length classes dominating Assemblage I and the upper size range dominating in Assemblages IV and both types of Assemblage V (Fig. 5a). For P. palmiformis, which was absent from Assemblage I (Fig. 5b), Assemblages II, III and IV had a majority of small individuals, while both forms of Assemblage $\mathrm{V}$ had mainly larger individuals (Fig. 5b). Approximately $60 \%$ of P. palmiformis in Assemblage IV were within the first length class. The vestimentiferan tube worm Ridgeia piscesae was absent from the first 3 Assemblages (I-III). Tube worms in Assemblage IV were almost all in the smallest length class, whereas Assemblage V-HF had the greatest proportion of larger individuals, with some exceeding $140 \mathrm{~mm}$ in length (Fig. 5c). 

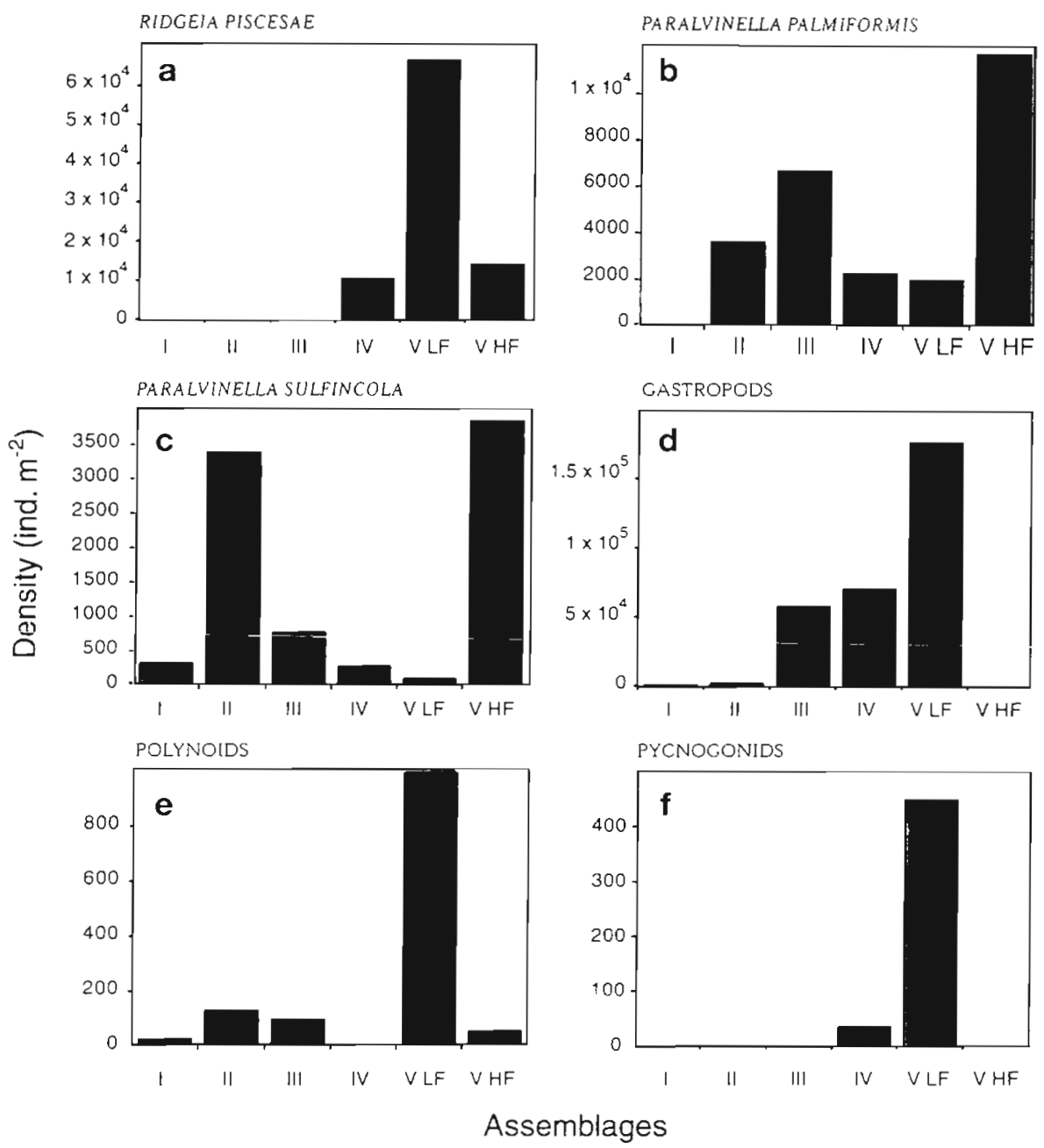

Fig. 3. Relative density (ind. $\mathrm{m}^{-2}$ ) of the 6 principal mega/macrofaunal species present in 5 distinct assemblages, including the low-flow and high-flow forms of Assemblage V. (a) Ridgeia piscesae, (b) Paralvinella palmiformis, (c) Paralvinella sulfincola, (d) gastropods, including Lepetodrilus fucensis, Depressigyra globulus, Provanna variabilis and Buccinum cf. viridum, (e) polynoids, (f) pycnogonids

\section{Biomass changes on $\mathrm{S} \& \mathrm{M}$}

The S\&M edifice underwent major changes in flow distribution during the 1991 to 1995 interval. The total number of black smoker vents decreased from 13 to 3 , while the total area of shimmering diffuse flow on the mapped western face increased by $75 \%$ (Sarrazin et al. 1997). In an effort to quantify the edifice-scale biological impact of these flow modifications we used faunal mosaic maps from Sarrazin et al. (1997) for the western face of S\&M in 1991, 1994 and 1995 to estimate total faunal biomass. For each year, total surface area colonized by each of the sampled assemblages was combined with the biomass data presented here (Table 4), to estimate faunal biomass for the mapped areas (Table 5). In all years, Assemblage V-LF dominated faunal biomass (Table 5). It constituted more than $75 \%$ of total wet weight biomass and more than $80 \%$ of faunal dry weight. Assemblage III's contribution to total edifice biomass was also relatively important $(\sim 2$ to $22 \%$ ). Total biomass (wet weight without tubes) of the west face decreased from $256 \mathrm{~kg}$ in 1991 to $233 \mathrm{~kg}$ in 1994 and $226 \mathrm{~kg}$ in 1995; a decrease of approximately $12 \%$. Dry weight biomass without tubes dropped from around $82 \mathrm{~kg}$ in 1991 to $70-71 \mathrm{~kg}$ in 1994 and 1995 . Total surface area of the western face of the edifice increased during the 1991 to 1995 interval, as did the total area colonized by the fauna (Table 5). Since Assemblage VI, dominated by senescent tube worms or their empty tubes, was not sampled, these calculations underestimate total faunal biomass.

\section{Available surface on vestimentiferan tubes}

Vestimentiferan tubes are extensively colonized by smaller species such as gastropods and polychaetes. We examined how these tubes effectively increase the space available for colonization by other organisms within the 3 sampled Ridgeia piscesae assemblages (Assemblage IV and both forms of Assemblage $V$ ). Tube surface was assumed to represent the lateral area 

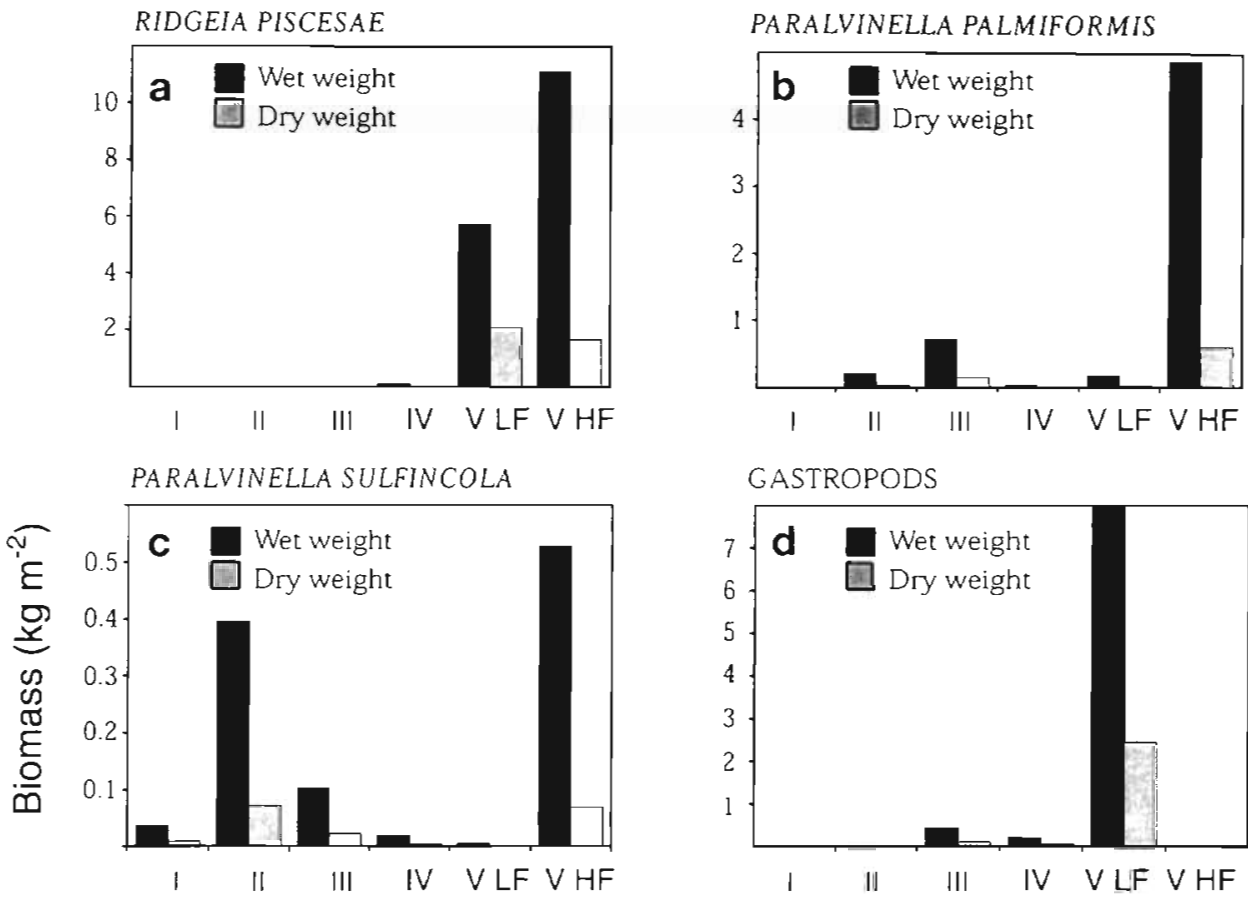

Fig. 4. Wet and dry biomass $\left(\mathrm{kg} \mathrm{m}^{-2}\right.$ without vestimentiferan tubes) of the 6 principal mega/macrofaunal species present in 5 distinct assemblages, including the low-flow and high-flow forms of Assemblage $V$. (a) Ridgeia piscesae, (b) Paralvinella palmiformis, (c) Paralvinella sulfincola, (d) gastropods, including Lepetodrilus fucensis, Depressigyra globulus, Provanna variabilis and Buccinum of viridum, (e) polynoids, (f) pycnogonids

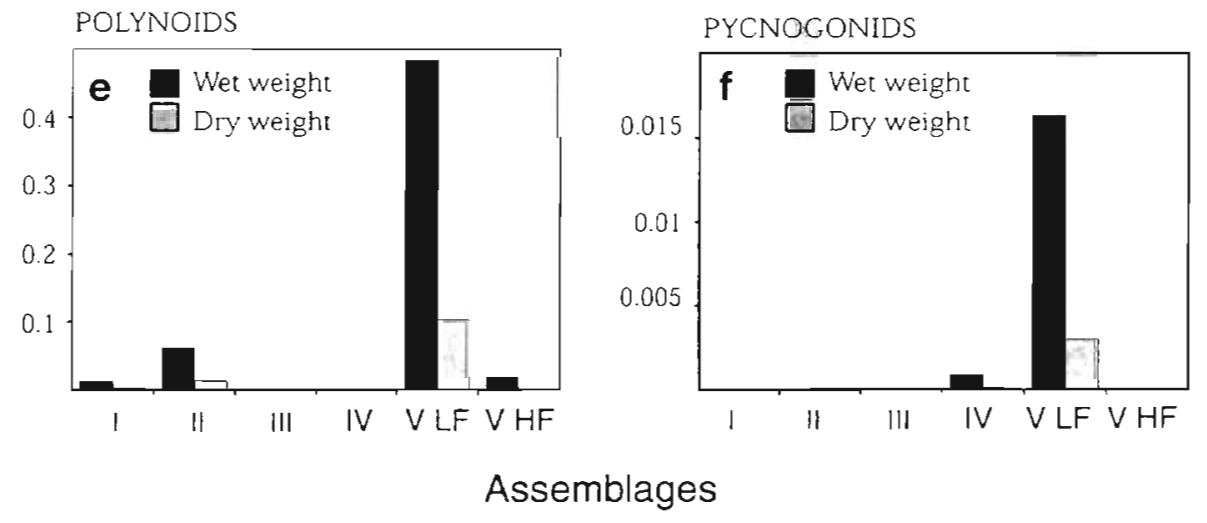

Table 5. Calculation of biomass changes of 5 distinct assemblages on the west face are of the Smoke and Mirrors sulfide edifice over a period of $4 \mathrm{yr}$. Surface area colonized by assemblages for 1991, 1994 and 1995 from Sarrazin et al. 1997. Total colonized area (C) as well as total uncolonized surfaces (Un) are given for each year. Since Assemblage VI was not sampled during this study, it was not included in the table, but surfaces colonized by this assemblage are included in total colonized area (C). Weights without vestimentiferan tubes are given in parentheses

\begin{tabular}{|c|c|c|c|c|c|c|c|c|c|}
\hline \multirow[t]{2}{*}{ Assemblage } & \multicolumn{3}{|c|}{ Surface area $\left(\mathrm{m}^{2}\right)$} & \multicolumn{3}{|c|}{ Total biomass (wet wt) } & \multicolumn{3}{|c|}{ Total biomass (dry wt) } \\
\hline & 1991 & 1994 & 1995 & 1991 & 1994 & 1995 & 1991 & 1994 & 1995 \\
\hline I & 10.9 & 8.1 & 4.2 & 0.57 & 0.42 & 0.22 & 0.12 & 0.09 & 0.05 \\
\hline II & 1.6 & 0 & 0 & 1.31 & 0 & 0 & 0.25 & 0 & 0 \\
\hline III & 6.3 & 40.6 & 31.3 & 7.92 & 51.02 & 39.33 & 1.88 & 12.10 & 9.33 \\
\hline IV & 2.1 & 3.7 & 0 & $\begin{array}{c}0.97 \\
(0.85)\end{array}$ & $\begin{array}{c}1.71 \\
(1.49)\end{array}$ & 0 & $\begin{array}{c}0.29 \\
(0.21)\end{array}$ & $\begin{array}{c}0.5 \\
(0.37)\end{array}$ & 0 \\
\hline V-LF & 17.0 & 12.4 & 12.9 & $\begin{array}{c}355.43 \\
(245.32)\end{array}$ & $\begin{array}{c}259.25 \\
(178.94)\end{array}$ & $\begin{array}{c}269.71 \\
(186.15)\end{array}$ & $\begin{array}{c}93.49 \\
(79.53)\end{array}$ & $\begin{array}{c}68.19 \\
(58.01)\end{array}$ & $\begin{array}{c}70.94 \\
(60.35)\end{array}$ \\
\hline Total C & 58.6 & 73.3 & 79.7 & $\begin{array}{c}366 \\
(256)\end{array}$ & $\begin{array}{c}312 \\
(232)\end{array}$ & $\begin{array}{c}309 \\
\{226)\end{array}$ & $\begin{array}{c}96 \\
(82)\end{array}$ & $\begin{array}{c}81 \\
(71)\end{array}$ & $\begin{array}{c}80 \\
(70)\end{array}$ \\
\hline Total Un & 20.5 & 10.2 & 7.6 & & & & & & \\
\hline Total Area & 79.1 & 83.5 & 87.3 & & & & & & \\
\hline
\end{tabular}



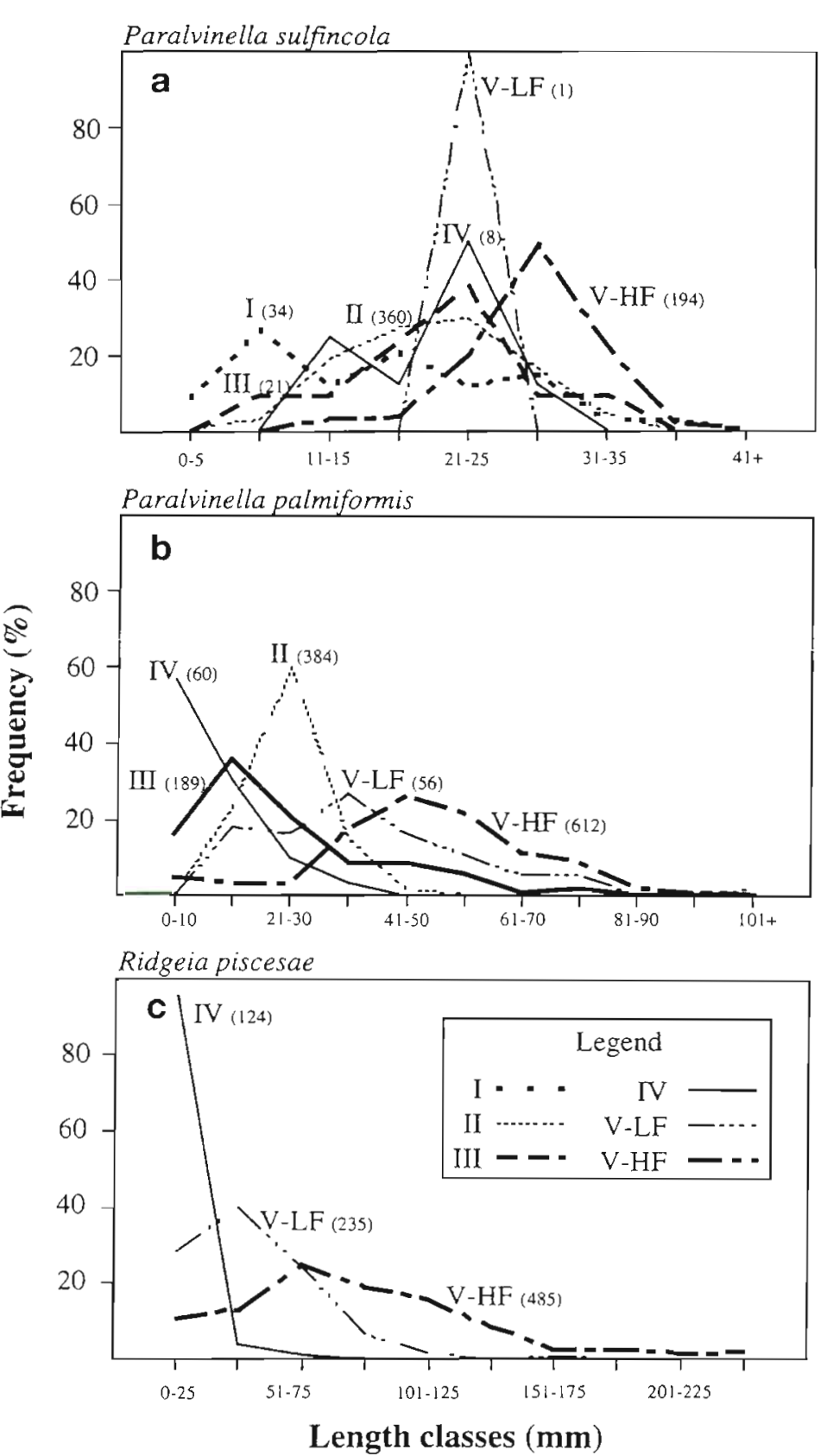

Fig. 5. Length class frequencies of 3 species of polychaetes, Paralvinella sulfincola, Paralvinella palmiformis and Ridgeia piscesae, present in the different assemblages sampled, including the low-flow and high-flow forms of Assemblage $V$. Number of individuals per sample indicated in parentheses

of a cone $(\pi \times$ [outside diameter/2] $\times$ length $)$. Mean tube area was first calculated from sampled tubes whose lengths and outside diametres were measured, and then extrapolated to the total number of individuals within each sample. The small $R$. piscesae tubes in Assemblage IV provided a surface area of approximately $0.039 \mathrm{~m}^{2}$, equivalent to $1.5 \times$ the sampled sul- fide surface $\left(0.029 \mathrm{~m}^{2}\right)$. In Assemblage V-LF tubes increased surface area by $0.67 \mathrm{~m}^{2}$, which represents $\sim 22 \times$ the sampled surface $\left(0.031 \mathrm{~m}^{2}\right)$. The area increase is even larger in Assemblage V-HF, where the estimated surface available on tubes was approximately $1.48 \mathrm{~m}^{2}(\sim 27 \times$ sampled edifice surface $)$. These results provide another view of the density of small organisms in vestimentiferan clumps. For example, density of the limpet Lepetodrilus fucensis calculated from total colonizable area (sampled surface + tube surface) in Assemblage V-LF would be 4779 ind. $\mathrm{m}^{-2}$ instead of 108226 ind. $\mathrm{m}^{-2}$ if only the sampled surface was considered. Field observations (Sarrazin unpubl. obs.) suggest some vertical zonation of smaller species within Assemblage $\mathrm{V}$ but this has not been quantitatively defined.

\section{DISCUSSION}

\section{Limitations}

Quantitative sampling at hydrothermal vents is still very challenging, particularly on irregularly shaped sulfide edifices. For example, this study used scaled 2-D images to determine total collection area for each faunal sample. The presence of any surface relief would have resulted in an underestimation of total area occupied by the sample, affecting density and biomass determinations. A similar problem would also be encountered using a fixed-area mechanical sampling device that closed across a planar surface. To evaluate the importance of this source of error we simulated simple relief by incorporating portions of a cylinder or a sphere in a $0.055 \mathrm{~m}^{-2}$ surface area (high-flow Assemblage $V$ ) and, calculating the influence of different heights of relief $(0.01 \mathrm{~m}$ to $0.1 \mathrm{~m})$ on the total calculated surface area, for both types of relief (Fig. 6). Adding a $2 \mathrm{~cm}$ relief (cylindrical or spherical) to a $0.055 \mathrm{~m}^{-2}$ planar area (size of Pacman grab) yields a total surface of $0.056 \mathrm{~m}^{-2}$, whereas for a $10 \mathrm{~cm}$ relief, resulting surface areas are $0.079 \mathrm{~m}^{-2}$ (cylinder) and $0.086 \mathrm{~m}^{-2}$ (sphere) (Fig. 6). The higher the relief, the greater the difference between the 2-D and 3-D areas is. In the extreme case considered here, where the sample area had a simple $10 \mathrm{~cm}$ spherical relief rather than being planar, biomass would be overestimated by a factor of 1.6. For example, instead of the $2.33 \mathrm{~kg} \mathrm{~m}^{-2}$ (dry weight without tubes), biomass of high-flow Assemblage $V$ would be $1.49 \mathrm{~kg} \mathrm{~m}^{-2}$ on a 


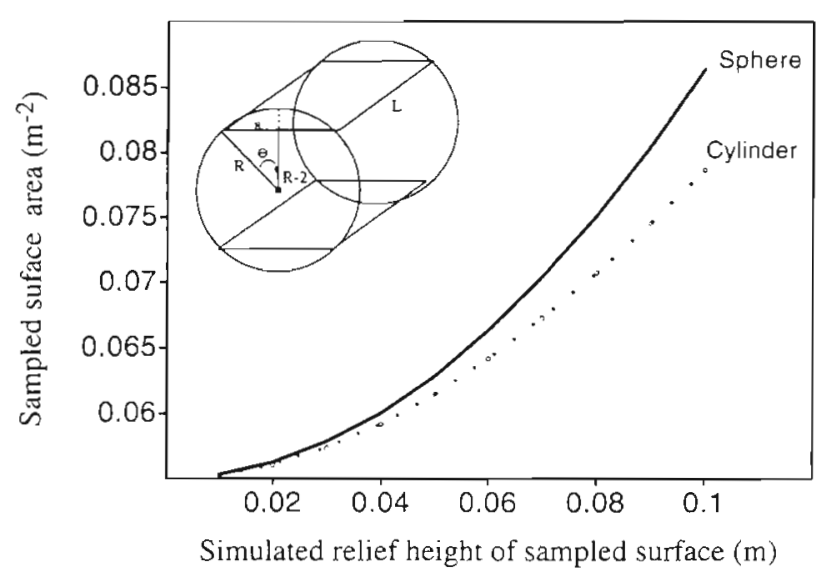

Fig. 6. Simulation of addition of simple spherical or cylindrical relief to a $0.055 \mathrm{~m}^{2}$ surface. Graph shows the influence of different heights of relief $(0.01 \mathrm{~m}$ to $0.1 \mathrm{~m})$ on the total calculated surface area for both types of relief. For visualization, a cylinder is presented as an example

$10 \mathrm{~cm}$ relief surface. Scaling sampled surfaces with 2 laser points, as done here, provides no information on relief. Multi-beam laser or acoustic ranging devices could provide some $3-\mathrm{D}$ information but would require very precise control of incident angle from source (submersible) to subject (sampled surface). Pitch and roll sensors have recently been fitted to the ROPOS vehicle but were not available at the time of this study.

Other limitations also need to be taken into account. The lack of concordance between sampling methods and the absence of replicates for assemblages limit interpretation of our results. Observed differences between 2 assemblages must be considered against unknown within-assemblage variations. Videoscopic studies have shown these assemblages to consistently recur on sulfide edifices of the Endeavour Segment but a more complete description of these faunal assemblages will require replicate sampling. The latter translates into considerable submersible bottom time, and a not-negligible impact on the vent fauna (Tunnicliffe 1990, Sarrazin et al. 1997). Many samples were completely or partially lost during collection attempts, and the successful collections presented here represent less than $25 \%$ of the total sampling effort. Sampling of individual faunal assemblages occurred in 2 different years and involved 2 different edifices, limiting the accuracy of total biomass estimates for the mosaic community colonizing the mapped western face of the S\&M edifice. Ash-free dry weight measurements may have provided a more accurate and comparable (especially with other ecosystems) measure of biomass, but in light of the overall size of the collected samples (over 15000 individuals), and in light of our major goal-describing the composition of the differ- ent assemblages identified from video imagery-we chose to limit our data sets to wet and dry weights. Finally, there are very few biomass estimates for vent communities, making it difficult to compare and critically evaluate our data. These limitations notwithstanding, this study is the first to quantitatively assess organism abundance and biomass in the suite of assemblages colonizing active hydrothermal edifices, in this case in the northeast Pacific

\section{Total sulfide edifice biomass: an estimation}

While hard substratum marine organisms are often limited by space availability (review by Lohse 1993), habitat expansion through sulfide accretion may attenuate or disrupt competition for space in vent assemblages (Tunnicliffe \& Juniper 1990, Sarrazin et al. 1997). S\&M occupied a footprint of only $50 \mathrm{~m}^{2}$ on the seafloor, whereas $207 \mathrm{~m}^{2}$ was available for faunal colonization on the accreted sulfide, as estimated below.

Total colonizable surface area was estimated for the entire edifice by integration of the area under the profile curve perpendicular to the long (N-S) axis of the structure (Fig. 7). Heights of different portions of S\&M in 1995 were plotted against widths using cartographic information from Sarrazin et al. (1997). Area under the profile curve was $66 \mathrm{~m}^{2}$ for the west side of the structure (Fig. 7). Since the east face of the structure is generally similar but has not been mapped, we assumed that the available surface there was comparable to that of the west face. We also added surfaces determined from profiles of the northern $\left(25 \mathrm{~m}^{2}\right)$ and southern faces $\left(50 \mathrm{~m}^{2}\right)$, for a total surface of approximately

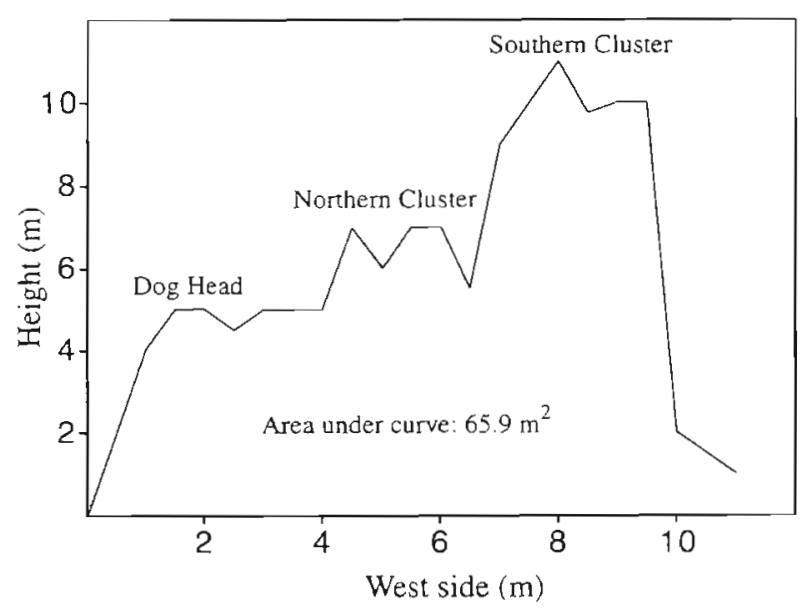

Fig. 7. Profile used to estimate surface area for the west face of S\&M edifice. Length $(x)$ and height $(y)$ of the structure were used to integrate total area under the curve. Total calculated area was $65.88 \mathrm{~m}^{2}$ for the west face, which gives an approximate surface area of $207 \mathrm{~m}^{2}$ for the entire edifice 
$207 \mathrm{~m}^{2}$ for the entire edifice. These calculations do not consider the 3-D relief of the edifice walls

Based on the 1995 estimate for total biomass of the west face of $S \& M(309 \mathrm{~kg}$, plus the unknown contribution of Assemblage VI), with $7.6 \mathrm{~m}^{2}$ of uncolonized surface, total biomass for the entire edifice would be around $969 \mathrm{~kg}$ wet weight with tubes $(709 \mathrm{~kg}$ without vestimentiferan tubes), or approximately $251 \mathrm{~kg}$ dry weight with tubes (219 kg without tubes). These biomass estimates are very approximate since less than $0.1 \%$ of the edifice surface was actually sampled.

\section{Structure-scale biomass changes}

Despite significant changes in fluid flow patterns between 1991 and 1995 on the Smoke and Mirrors edifice (Sarrazin et al. 1997), the total biomass of the western face, as estimated above, did not vary a great deal over the 4 yr observational period. Only $\sim 57 \mathrm{~kg}$ of biomass (wet weight with tubes) disappeared $(16 \%$ of total biomass), most of it during the 1991 to 1994 interval. The major contribution of the low-flow Ridgeia piscesae assemblage to total edifice biomass, together with its relatively constant surface occupation, likely explains the small variation in overall edifice biomass Thus, even though the surface colonized by Assemblage I decreased appreciably, the impact on the edifice total biomass was negligible. Vestimentiferandominated Assemblage $\mathrm{V}$ accounted for $96 \%$ of the biomass in 1991 (wet weight with tubes), and a reduction of its total surface between 1991 and 1994 (-27\%) likely explains the 1991 to 1994 biomass decrease. Total biomass change over the 1994 to 1995 interval was negligible $(-2 \%)$. These calculations quantitatively confirm previous suggestions of the high contribution to vent biomass by vestimentifera (Fustec et al. 1988, Tunnicliffe et al. 1985, 1993). The observation that the limpet Lepetodrilus fucensis comprised more than half of the wet and dry weight biomass (excluding vestimentiferan tubes) in low-flow Assemblage $V$ indicates that there are situations where a high biomass of grazing (or filter-feeding) organisms can be supported.

\section{Assemblage characteristics}

Overall, our faunal data show that the original descriptions of 5 assemblages from video imagery were relatively accurate for the dominant mega/macrofaunal species (Sarrazin et al. 1997), confirming the utility of imaging as a tool for determining the composition of the mega/macrofaunal assemblages which account for most of the total biomass in this environment. Densities observed for gastropod species and the vestimentiferan Ridgeia piscesae are high, but numbers on the order of thousands of individuals per square metre have been reported elsewhere for different vent-associated species (Hessler \& Smithey 1983, Laubier et al. 1986, Segonzac 1992, Chevaldonné \& Jollivet 1993).

Density and biomass tended to increase along an observed decreasing fluid flow gradient from Assemblage I to $\mathrm{V}$ (low-flow). As reported by Fustec et al. (1988), biomass of higher temperature Assemblages (I-III) was lower than for lower temperature Assemblages (IV and V-LF). Dense shrimp populations colonizing high-temperature areas of edifices located on the mid-Atlantic Ridge also have a relatively low biomass (1 to $1.2 \mathrm{~kg} \mathrm{~m}^{-2}$; Segonzac 1992). This can be attributed to the absence of symbiont-bearing species in higher temperature habitats. The high-flow Assemblage $\mathrm{V}$ diverged from this pattern. It had a relatively high biomass but low species richness in a regime of vigorous fluid flow. The very particular nature of the Assemblage V-HF habitat is likely responsible for this situation, but the exact mechanism remains to be defined. Smaller species appear to be intolerant of the warm (up to $37^{\circ} \mathrm{C}$ ), turbulent hydrothermal flow that bathes the tubes of the V-HF Ridgeia piscesae morphotype, possibly because of a lack of sufficient dissolved oxygen.

\section{Comparison with other ecosystems}

Despite much discussion of the exceptional biomass occurring at deep-sea hydrothermal vents (Corliss et al. 1979, Hessler \& Smithey 1983, Felbeck et al. 1985, Grassle 1985, Jannasch \& Mottl 1985, Laubier et al. 1986, Childress et al. 1987, Lutz \& Kennish 1993, Jollivet 1996), there are few published faunal biomass measurements because of the difficulty in obtaining quantitative samples. In previous studies (Hessler \& Smithey 1983, Somero et al. 1.983, Brault et al. 1985, Fustec et al. 1988, Chevaldonné \& Jollivet 1993), vent community biomass has been determined from a few collected individuals and extrapolated to entire fields or structures using density estimates derived from video imagery. Previous biomass estimates have been limited to principal mega/macrofaunal species, but resulting values are still comparable to or higher than those of the most productive benthic assemblages (Fustec et al. 1988, Chevaldonné \& Jollivet 1993, review by Lutz \& Kennish 1993).

Biomass estimates for the deposit/suspension feederdominated assemblages examined here (I-III) are comparable to those reported for similar assemblages on East Pacific Rise (EPR) sulfide chimneys. This may reflect similar food limitations. Values for the 2 alvinel- 
lid polychaete species (wet weight without tubes) varied, from $0.052 \mathrm{~kg} \mathrm{~m}^{-2}$ for the Paralvinella sulfincola assemblage (I) to $0.818 \mathrm{~kg} \mathrm{~m}^{-2}$ for $P$, sulfincolal $P$. palmiformis assemblage (II), within the range $(0.15$ to $0.5 \mathrm{~kg} \mathrm{~m}^{-2}$ ) reported by Chevaldonné \& Jollivet (1993) for alvinellids on EPR chimneys. If the contribution of alvinellid tubes is removed from the $2.2 \mathrm{~kg} \mathrm{~m}^{-2}$ calculated by Desbruyères \& Laubier (1991) for the same area of the EPR $10.7 \mathrm{~kg} \mathrm{~m}^{-2}$ in Chevaldonné \& Jollivet 1993), our data are also comparable. Fustec et al. (1988) estimated $2.4 \mathrm{~kg} \mathrm{~m}^{-2}$ for an EPR high-temperature assemblage that includes alvinellids, detritus feeders and filter feeders. This latter estimate is slightly higher than our estimate for Assemblage III (1.3 $\mathrm{kg} \mathrm{m}^{-2}$ ), which might be considered analogous. Finally, as mentioned by Chevaldonné \& Jollivet (1993), the biomass of $16 \mathrm{~kg} \mathrm{~m}^{-2}$ obtained by Brault et al. (1985) for a mix of alvinellid species (wet wt with tubes) appears to be unrealistic. Thus, even without the tubes $\left(5 \mathrm{~kg} \mathrm{~m}^{-2}\right)$, as calculated by Chevaldonne \& Jollivet (1993), the Brault et al. (1985) biomass estimate for this assemblage is at best 2 times greater than other published figures for the same area of the EPR (Fustec et al. 1988, Desbruyères \& Laubier 1991, Chevaldonné \& Jollivet 1993).

The highest biomass, $20.9 \mathrm{~kg} \mathrm{~m}^{-2}$ (wet wt with tubes), reported for the low-flow Ridgeia piscesae assemblage (V) falls between 2 estimates for related assemblages: $53.5 \mathrm{~kg} \mathrm{~m}^{-2}$ (with tubes) for a vestimentiferan Riftia pachyptila/mussel Bathymodiolus thermophilus assemblage (Fustec et al. 1988 in Desbruyères \& Laubier 1991 ) and $8.5 \mathrm{~kg} \mathrm{~m}^{-2}$ for a low-temperature vestimentiferan assemblage examined by Fustec et al. (1988). Further comparison of our vestimentiferan assemblage data with those of Fustec et al. (1988) is hampered by the fact that their estimates are derived from measurement of a mean wet weight of preserved specimens multiplied by density estimates obtained from video imagery without internal scaling. Also, their estimate does not include accompanying species, although more than $80 \%$ of total biomass in our tube worm dominated collections was comprised by the tube worms.

Similar biomass levels are found in cold seep ecosystems. Bivalve assemblages at cold seeps can attain 10 to $51 \mathrm{~kg} \mathrm{~m}^{-2}$ (wet weight without shells; Ohta \& Laubier 1987, Hashimoto et al. 1989, Olu et al. 1996), similar to the 10 to $15 \mathrm{~kg} \mathrm{~m}^{-2}$ (wet weight) estimated by Hessler \& Smithey (1983) for vent bivalves. In total biomass, deep-sea chemosynthetically based ecosystems (vents and seeps) appear comparable to the most productive marine ecosystems (Table 6) and greatly exceed values for the surrounding deep sea, where benthic biomass is of a the order of a few grams per $\mathrm{m}^{2}$ (Gage \& Tyler 1991). With the exception of wood fouling fauna, reported faunal biomass values for photo- synthetic marine environments are $<1.0 \mathrm{~kg} \mathrm{~m}^{-2}$, similar to hydrothermal alvinellid assemblages (Table 6). Comparison with other ecosystems is limited by the fact that several published estimates are reported as ash-free dry weight, while here, and in most other published biomass estimates for vent and seep communities, data are reported as wet or dry weights only.

\section{Species richness}

Habitat conditions appeared to influence species richness. Surfaces with more severe hydrothermal conditions (I, II and V-HF) had fewer species than surfaces receiving more moderate hydrothermal input (III, IV and V-LF). This suggests that fewer species have the physiological tolerance required to live in harsher conditions of exposure to $\mathrm{H}_{2} \mathrm{~S}$ and hypoxia. Since our species richness is only an index, there are limitations to this interpretation. Sampled surface area varied from 0.029 to $0.118 \mathrm{~m}^{2}$, so differences in species richness could be influenced by sample size (Bell et al. 19911, although the sample with the lowest species richness came from the largest surface area. Furthermore, our richness index underestimates the real number of species present. For example, up to 4 polynoid species were present in Assemblage V-LF but the richness index used here considered polynoids as a single faunal group.

\section{Refining the dynamic succession model}

In their study of inter-annual variation in the patchwork of faunal assemblages colonizing the S\&M edifice, Sarrazin et al. (1997) suggested that community transitions were the result of gradual environmental change, perturbations and biological processes, all acting in a spatially heterogeneous and unpredictable way. These observations led to a succession model in which there was progressive transition from colonization of new sulfide mineral surfaces by alvinellid polychaetes through to development of vestimentiferan tube worm assemblages to their senescence, as hydrothermal fluid supply diminishes and eventually ceases. The model also provided for cases of reactivation of fluid flow on cooling surfaces, which could result in a reversion to an earlier successional stage (Sarrazin et al. 1997)

Do the between-assemblage differences in biomass and species composition observed here represent succession of a series of discrete assemblages or are they better described as different expressions of a single community? Use of the term community is still greatly argued by ecologists (review by Auerbach \& Shmida 
Table 6. Biomass (wet [W] or dry [D] weight) of different marine assemblages in chemosynthetically and photosynthetically based ecosystems

\begin{tabular}{|c|c|c|c|}
\hline Location & Type of assemblage & $\begin{array}{l}\text { Biomass } \\
\left(\mathrm{kg} \mathrm{m}^{-2}\right)\end{array}$ & Source \\
\hline \multicolumn{4}{|c|}{ Chemosynthetically based ecosystems } \\
\hline \multirow{6}{*}{$\begin{array}{l}\text { Hydrothermal vents } \\
\text { Juan de Fuca Ridge, } \\
\text { northeast Pacific Ocean }\end{array}$} & & & \multirow{6}{*}{$\begin{array}{l}\text { This study } \\
\text { (with vestimentiferan tubes) }\end{array}$} \\
\hline & Alvinellid assemblages & $\begin{array}{l}0.054-0.82(W) \\
0.012-0.154(D)\end{array}$ & \\
\hline & Alvinellid \& gastropod & $1.75(\mathrm{~W})$ & \\
\hline & assemblages & $0.39(\mathrm{D})$ & \\
\hline & Vestimentiferan & $0.46-20.91(\mathrm{~W})$ & \\
\hline & assemblages & $0.14-5.5$ (D) & \\
\hline Galapagos, Pacific Ocean & Riftia pachyptila assemblage & $10-15(W)$ & Childress in Somero et al. (1983) \\
\hline Galapagos, Pacific Ocean & Mussel population & $10.1(\mathrm{~W})$ & Hessler \& Smithey (1983) \\
\hline \multirow[t]{2}{*}{ EPR, Pacific Ocean } & Serpulid population & $0.08(\mathrm{~W})$ & Brault et al. $(1985)$ \\
\hline & Alvinelidid population & $16(\mathrm{~W})$ & \\
\hline EPR, Pacific Ocean & High-and low-temperature assemblages & $2.4 \& 8.5(\mathrm{~W})$ & Fustec et al. (1988) \\
\hline Mid-Atlantic Ridge & Shrimp populations & $1-1.2(\mathrm{~W})$ & Segonzac (1992) \\
\hline EPR, Pacific Ocean & Alvinellid population & 0.14 to $0.52(\mathrm{~W})$ & Chevaldonné \& Jollivet (1993) \\
\hline \multicolumn{4}{|l|}{ Seeps } \\
\hline Japanese trenches & Vesicomyidae populations & $16-51(W)$ & Onta \& Laubier $\{1987\}$ \\
\hline Sagami Bay & Vesicomyidae populations & $10(\mathrm{~W})$ & Hashimoto et al (1989) \\
\hline Central Shagerrak Danish coast & Mega/macrofauna & $0.125(W)$ & Dando et al. (1994) \\
\hline Peruvian active margin & Bivalve populations & $30-50(W)$ & Olu et al. (1996) \\
\hline \multicolumn{4}{|c|}{ Photosynthetically based ecosystems } \\
\hline \multicolumn{4}{|l|}{ Flora } \\
\hline Venice lagoon & Macroalgae & $0-20(W)$ & Sfriso et al. (1993) \\
\hline Lagoon & Macrophytic seagrass & $0.41-0.90(\mathrm{~W})$ & In: Ansari \& Parulekar (1994) \\
\hline James Bay (Canada) & $\begin{array}{l}\text { Eelgrass meadows } \\
\text { Leaf biomasses }\end{array}$ & $0.03-0.7(D)$ & Lalumière et al. (1994) \\
\hline Different locations & $\begin{array}{l}\text { Eelgrass meadows } \\
\text { Leaf biomasses }\end{array}$ & $0.007-1.8(\mathrm{D})$ & Review by Lalumière et al. (1994) \\
\hline Different locations & Seagrass biomasses & $0.003-0.3(\mathrm{D})$ & Review by Dawes et al. (1995) \\
\hline Estuary & Macroalgae & $<0.0029(\mathrm{~W})$ & Platell \& PIotter (1996) \\
\hline New South Wales & Green algae in deep-reef habitat & $\begin{array}{l}5.2 \pm 1.1(W) \\
<11(W)\end{array}$ & Davis et al. (1997) \\
\hline Meditteranean Sea & Algae in deep-reef habitat & $1.8-5.3(W)$ & Review by Davis et al. (1997) \\
\hline \multicolumn{4}{|l|}{ Fauna } \\
\hline Suruga Bay (Japan) & Infaunal ophiuroids & $0.017-0.037(\mathrm{~W})$ & Fujita \& Ohta (1990) \\
\hline Barents Sea & Sympagic fauna & $0-0.012(\mathrm{~W})$ & $\begin{array}{l}\text { Loenne \& Gulliksen (1990) } \\
\text { Gulliksen (1984) }\end{array}$ \\
\hline \multirow[t]{2}{*}{ Deep-sea } & Macrobenthos & $0.004-0.003(W)$ & Shiramaya (1983 in \\
\hline & Meiobenthos & $0.00005-0.0015$ (D) & Gage \& Tyler (1991) \\
\hline Swedish west coast & Benthic macrofauna & $0.001-0.086(W)$ & Rosenberg et al. (1991) \\
\hline Andaman Sea (Thailand) & Benthic macrofauna & $0.001-0.23(W)$ & Bussarawit (1992) \\
\hline Southwest Indian Ocean & Benthic fauna & $0.000022-0.001 .12$ (D) & Ingole et al. (1992) \\
\hline Arcachon Bay (France) & Benthic macrofauna & $0.0013-0.043(\mathrm{D})$ & Bachelet \& Dauvin (1993) \\
\hline Bothnian Sea & Bottom fauna assemblages & $0.075-0.28(\mathrm{~W})$ & Mattila (1993) \\
\hline Mormugao harbour, Indıa & Wood fouling fauna & $1.1-10.7(\mathrm{~W})$ & Raveendran \& Wagh (1993) \\
\hline Central Skagerrak, Danish coast & Non-seep mega-macrofauna & $0.039(\mathrm{~W})$ & Dando et aI. (1994) \\
\hline Arctic fjord & Polychaete assemblages & $<0.1$ (W) & Kendall (1994) \\
\hline Florida (USA) & Invertebrates & $0-0.29(W)$ & Vose \& Bell (1994) \\
\hline Antartic and subantarctic areas & Macrobenthos & $0.020-6.0(\mathrm{~W})$ & Review by Gambi et al. (1994) \\
\hline Monaco (France) & Fish fauna & $0.002-0.2(\mathrm{~W})$ & Barnabe et al. (1994) \\
\hline South Japan cove & Benthic fauna & $0.01-0.123(w)$ & Tsutsumi (1995) \\
\hline Trenches of different locations & Macro-and meiofauna & $0.00001-0.040\left(W^{\prime}\right)$ & Review by Richardson et al. (1995) \\
\hline Atlantic abyssal sites & Megafauna & $0.036-0.39(\mathrm{~W})$ & Review by Briggs et al. (1996) \\
\hline Costa-Rican mangrove & Thais kiosquiformis Duclos & $0.0064(\mathrm{D})$ & Koch \& Wolff (1996) \\
\hline \multirow[t]{2}{*}{ Mangrove of different locations } & Epifauna & $0.13-0.41(\mathrm{~W})$ & Reviewed by \\
\hline & Macrozoobenthos & $\begin{array}{c}0.008-0.017(\mathrm{D}) \\
<0.4(\mathrm{~W})\end{array}$ & $\begin{array}{l}\text { Koch \& Wolff (1996) } \\
\text { Zettler (1996) }\end{array}$ \\
\hline Nueces Bay (Texas) & Benthic macrofauna & $0.00009-0.009$ (D) & Mannino \& Montagna (1997) \\
\hline \multirow{4}{*}{$\begin{array}{l}\text { Fauna and flora } \\
\text { South China Sea }\end{array}$} & & & \\
\hline & Fringing reef assemblages & & \\
\hline & Soft corals & $19.2-45.9(\mathrm{~W})$ & Latypov (1993) \\
\hline & Macrophytes & & \\
\hline Antartic & Phyto- and zoobenthic associations & $0.02-2.4(W)$ & Gambi et al. (1994) \\
\hline North Brittany & Subtidal rocky assemblages & $4.75-29(W)$ & Castric-Fey $(1996)$ \\
\hline Caribbean coral reefs & Coral reef assemblages & $5.05(\mathrm{~W})$ & $\begin{array}{l}\text { Review of literature and modeling } \\
\text { by Opitz (1996) }\end{array}$ \\
\hline
\end{tabular}




\section{Revised dynamic succession model}

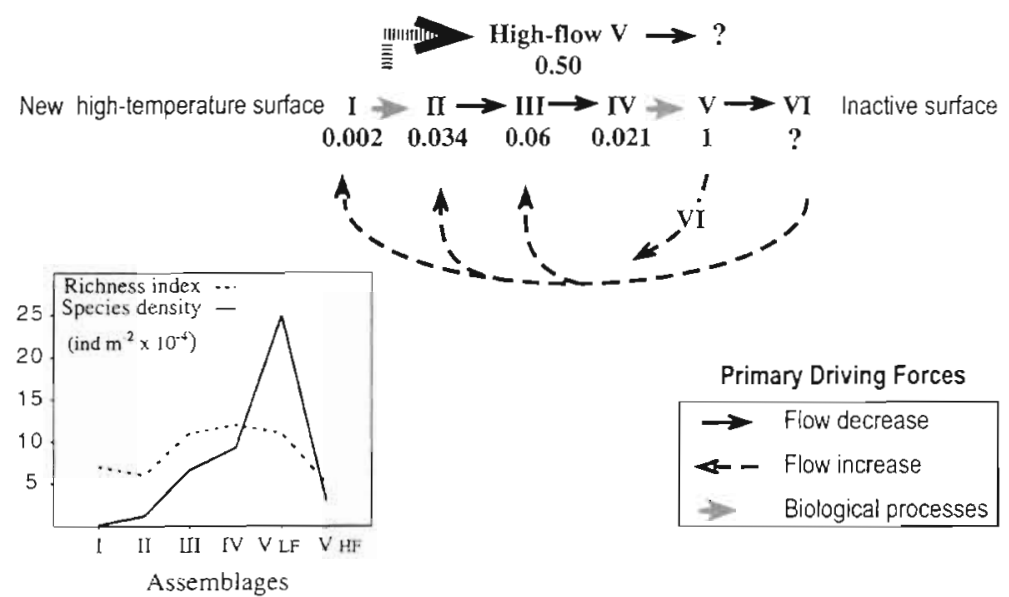

Fig. 8. Revised dynamic succession model for hydrothermal edifice assemblages of the Juan de Fuca Ridge. Relative biomass (dry weight without vestimentiferan tubes; normalized to 1) and species density and richness index are added to the previous model proposed by Sarrazin et al. (1997). Primary driving forces for progressive community changes are flow modifications and biological processes such as growth and habitat alteration (biomineralization, flow modification, etc.). Assemblages can abruptly disappear at any point in the sequence through stoppage of fluid flow or sudden high-temperature reactivation. Assemblages I-III are dominated by mobile species and likely to migrate in response to flow variations. Assemblage $\mathrm{V}$ has 2 distinct forms that are dependent on flow intensity. The unusual highflow form of Assemblage $V$ appears to develop in high fluid flow environments. Only tube-worm-dominated low-flow Assemblage $V$ produces a visible senescence (Assemblage VI), as a result of flow extinction or intense reactivation. Perturbations that do not affect flow regimes may permit progressive recolonization by the original assemblage

Intermediate stages in the transition from Assemblage I to Assemblage II are seen and can be related to visible mineral accretion (Sarrazin et al. 1997). Habitat modifications by Paralvinella sulfincola mucus secretion (Paradis et al. 1988, Juniper et al. 1992) would allow a gradual colonization of these high-temperature habitats by the mobile polychaete P. palmiformis. Comparison of tissue-level $\mathrm{H}_{2} \mathrm{~S}$ detoxification rates (Martineu et al. 1997) support that $P$. palmiformis would be adapted to less severe hydrothermal conditions than $P$. sulfincola. Tunnicliffe et al. (1993) have also suggested that $P$. palmiformis could require a rough surface to anchor its body, a role that could be played by the irregular texture of the marcasite crust formed by $P$. sulfincola.

The transition from Assemblage II to Assemblage III mainly involves the addition of greater numbers of the limpets and snails, a major reduction in Paralvinella sulfincola density, and the development of milder hydrothermal conditions (Sarrazin et al. in press). Invasion of massive numbers of gastropods could have an impact on available food sources and may increase interspecific competition. While competition with the suspension feeder $P$. palmiformis is less likely, the feeding strategy of grazer gastropods could potentially inter-

1993). Succession is a more or less orderly process of community change that is partly a result of changing physical habitat (here fluid characteristics) and partly caused by the activities of the previous community's organisms (Odum 1969, see also review by Keeton \& Gould 1993). For succession to be orderly and therefore predictable, certain species must precede others (Connell 1972). Environmental change should also follow a predictable trend. Results of the present study were used to refine the Sarrazin et al. (1997) succession model through the addition of a quantitative dimension (Fig. 8) and the inclusion of the high-flow Assemblage $V$. This enables the model to be tested against criteria commonly used to describe biological succession.

In this revised model, as in the previous version, newly formed sulfide surfaces are first colonized by the Paralvinella sulfincola assemblage (Juniper et al. 1992, Juniper 1994, Sarrazin et al. 1997). This initial step has been documented by time-lapse photography (Juniper et al. 1992): the subsequent progressive addition of other species (Sarrazin et al. 1997) has never been observed in its entirety on any surface fere with the surface deposit feeder $P$. sulfincola. The preference of this species for extreme habitat conditions could be explained by a poor ability to compete under conditions that allow colonization by gastropods.

The observation of small vestimentiferan tube worms growing up through a background of limpets, snails and palm worms is clear evidence that Assemblage IV develops next. The progressive growth of small tube worms would increase available space for organism colonization and lead to the more complex low-flow Assemblage $\mathrm{V}$. This species-rich community harbors dense populations of organisms and contributes significantly to the overall biomass of sulfide edifices. Ridgeia piscesae could act as a 'keystone species' by providing substratum (alvinellids, gastropods) and food (polynoids, hesionids) to smaller organisms (Tunnicliffe et al. 1997). Furthermore, the 3-D structure of a vestimentiferan clump increases habitat heterogeneity by, for example, creating a sheltered, less extreme and better oxygenated habitat for organisms that colonize the upper parts of the tubes. At present, the 3-D microscale distribution of species in tube worm 
Table 7 Comparison between the Keeton \& Gould succession criteria and the observations made in the 6 faunal assemblages colonizing high-temperature hydrothermal edifices located on the Juan de Fuca Ridge

\begin{tabular}{|c|c|}
\hline Criterion & Observations \\
\hline $\begin{array}{l}\text { 1. Continuous change of species composition during } \\
\text { succession. Change most rapid in earlier stages }\end{array}$ & Observed here \\
\hline $\begin{array}{l}\text { 2. Total number of species increases rapidly at first and } \\
\text { becomes more or less stabilized in the older stages }\end{array}$ & Observed here \\
\hline $\begin{array}{l}\text { 3. Net primary productivity increases until it reaches a } \\
\text { stable high level }\end{array}$ & $\begin{array}{l}\text { No productivity data. High biomass (vestimentifera) of } \\
\text { autotrophic symbiosis in Assemblage } V\end{array}$ \\
\hline $\begin{array}{l}\text { 4. Store of inorganic nutrients increased. Increased } \\
\text { proportion of store held in autotroph tissue }\end{array}$ & $\begin{array}{l}\text { Nutrient stores will increase with biomass. No data on } \\
\text { partitioning but biomass of autotrophs is high in both } \\
\text { forms of Assemblage } V\end{array}$ \\
\hline $\begin{array}{l}\text { 5. Total biomass and organic detritus increase to stable } \\
\text { level }\end{array}$ & Biomass increase observed. No data on detritus \\
\hline $\begin{array}{l}\text { 6. Autotroph height/massiveness increase. Leads to habitat } \\
\text { differentiation }\end{array}$ & $\begin{array}{l}\text { Tube worm growth increases surface area for colonization. } \\
\text { No data on habitat differenlidion but the } 3-D \text { structure of } \\
\text { a worm clump can provide a range of environmental } \\
\text { conditions }\end{array}$ \\
\hline 7. Food web complexity increases & No data \\
\hline
\end{tabular}

assemblages is unknown. The ensuing demise of the tube worms (VI) is a logical prediction, as a result of cessation of hydrothermal fluid flow.

The high-flow Assemblage $\mathrm{V}$ is less common than the other form at Juan de Fuca hydrothermal vents. It appears to be an opportunistic community that was observed to overgrow Assemblage I and/or II (J.S. pers. obs.). It develops in unusual environmental conditions characterized by high levels of $\mathrm{H}_{2} \mathrm{~S}$ ( $\mathrm{G}$. Massoth unpubl. data) and high fluid flow. These conditions appeared to be highly favorable for the growth of some species (tube worms \& alvinellids) while they could have been limiting for others (gastropods). The apparent underutilization of the additional substratum available (vestimentiferan tubes) suggests that space limitation can be subordinate to chemical conditions in determining the number of species present in vent assemblages.

These hydrothermal assemblages follow other trends commonly observed in biological succession (Table 7 ). Biomass (Fig. 8) and autotroph (vestimentifera) height and massiveness increase with species diversity, as probably do net primary productivity and food web complexity, for which there are presently no data available. One of the more unique aspects of this sulfide edifice community is the fact that succession operates at the level of the decimeter-scale patches that form the overall faunal mosaic. Sarrazin et al. (1997) postulate that this patchiness corresponds to the predominant spatial scale of physical perturbations and fluid flow heterogeneity on large edifices. Faunal change within individual patches will occur through larval recruitment and migration of mobile species from neighbouring surfaces, neither of which have been quantified.

\section{CONCLUSION}

Biomass estimates in the vent environment were very approximate prior to the Fustec et al. (1988) study, and it is still very difficult to successfully collect quantitative samples at vents. The development of quantitative sampling tools for submersible use is becoming essential to studying the ecology of vent assemblages, especially to account for smaller species that are largely underestimated in videoscopic analysis and submersible claw grabs. At the same time, studies must consider the fact that perturbation resulting from sampling activities can significantly affect local faunal dynamics and fluid flow (Tunnicliffe 1990, Sarrazin et al. 1997). Sampling remains essential to biomass determination and verification of species composition, but considerable quantitative ecological information can be derived from analyses of submersible-collected imagery, with sampling serving primarily as a ground truthing tool. In addition to being non-invasive, imagery has the advantages of easy acquisition (and replication) and suitability for the synoptic study of large areas.

The colonization patterns observed on the S\&M high-temperature edifice are limited to northeast 
Pacific vent sites. While most of these edifices are covered by a mosaic of 5 to 6 assemblages, edifices from the Eastern Pacific only harbor 2 or 3 assemblages: high-temperature alvinellid assemblages (I and II) and low-temperature vestimentiferan assemblages (V-LF) (Fustec et al. 1988, Shank et al. 1998). The intermediate (III and IV) as well as the senescent assemblages (VI) appear to be absent. Similar patterns are observed on southeastern high-temperature edifices (J.S. pers. obs.). Another major difference is the surface covered by the fauna. While northeast Pacific structures can be totally covered by organisms, edifices from the eastern and southeastern Pacific are only partially colonized. Environmental factors (temperature \& chemistry), fluid supply, larval supply and the stability of sulfide substrata are among the factors that could potentially limit the distribution of faunal assemblages on a single edifice. In addition, the relative abundance of the sulfide edifice habitat (versus diffuse venting through basalt) within different biogeographic areas may have influenced how vent faunas have evolved to exploit it (Juniper et al. 1990).

Acknowledgements. This work would not have been possible without the field support of the pilots of ROPOS and the crews of the CSS 'John P. Tully' and the 'Thomas G. Thompson' This research was sponsored by NSERC Canada, Fisheries and Oceans Canada and the National Science Foundation. J.S. was supported by post-graduate fellowships from NSERC (Canada), FCAR (Québec) and GÉOTOP (UQAM). We are particularly grateful to C. White, M. Touré, K. Rohrbach, B. Claiborne, J. Oubraham, C. Lévesque, D. Grelon and D. Puchault, who kindly helped in sorting and measuring organisms. Thanks also go to J.-C. Marechal for his help with geometric calculations. We thank 4 anonymous reviewers for their constructive comments, and Dr Verena Tunnicliffe for many productive discussions during preparation of this manuscript.

\section{LITERATURE CITED}

Ansari ZA, Parulekar AH (1994) Meiobenthos in the sediments of seagrass meadows of Lakshadweep atolls, Arabian sea. Vie Milieu 44 (3-4):185-190

Auerbach M, Shmida A (1993) Vegetation changes along an altitudinal gradient on $\mathrm{Mt}$ Hermon, Israel-no evidence for discrete assemblages. J Ecol 81:25-33

Bachelet G, Dauvin JC (1993) The quantitative distribution of benthic macrofauna in intertidal sands of Arcachon Bay. Oceanol Acta 16 (1):83-97

Barnabe G, Chauvet C, Boisson M (1994) Evaluation of fish fauna of Monaco's submarine nature reserve. Bull Mar Sci $55(2-3): 1326-1327$

Bell SS, McCoy ED, Mushinsky HR (1991) Habitat structure: the physical arrangement of objects in space. Chapman and Hall, London

Brault M, Marty JC, Saliot A, Laubier L (1985) Traceurs biogéochimiques (hydrocarbures et acides gras) dans l'eau de mer environnant un peuplement hydrothermal de la ride Est-Pacifique à $13^{\circ}$ N. C R Acad Sci Paris, Ser III, 301:1-8
Briggs KB, Richardson MD, Young DK (1996) The classification and structure of megafaunal assemblages in the Venezuela Basin, Caribbean Sea. J Mar Res 54(4):705-730

Bussarawit S (1992) Quantitative survey of macrobenthic faund in a Chicoreus ramosus fishing ground off the coast of Trang, Andaman Sea, Thailand. Spec Publ Phuket Mar Biol Cent 11:121-130

Campbell L, ChowFraser P (1995) Differential effects of chemical preservatives and freezing on the length and dry weight of Daphnia and Diaptomus in an oligotrophic lake. Arch Hydrobiol 134:255-269

Castric-Fey A (1996) Richesse et biodiversité en mer mégatidale: communautés sublittorales rocheuses de la région Trebeurden-Ploumanach (Nord Bretagne, France). Cah Biol Mar 37 (1):7-31

Chevaldonné P (1996) Écologie des cheminées hydrothermales actives. Thèse de Doctorat. Université de la Méditerranée, Marseille, France

Chevaldonné P, Jollivet D (1993) Videoscopic study of deepsea hydrothermal vent alvinellid polychaete populations: biomass estimation and behaviour. Mar Ecol Prog Ser 95: $251-262$

Chevaldonné P, Desbruyères D, Le Haître M (1991) Timeseries of temperature from three deep-sea hydrothermal vent sites. Deep-Sea Res 38:1417-1430

Childress JJ, Felbeck H, Somero GN (1987) Symbiosis in the deep sea. Sci Am 255:114-120

Connell JH (1972) Community interactions on marine rocky intertidal shores. Annu Rev Ecol Syst 3:169-191

Corliss JB, Dymond J, Gordon LI, Edmond JM, Von Herzen RP, Ballard RD, Green K, Williams D, Bainbridge A, Crane $K$, van Andel TH (1979) Submarine thermal springs on the Galapagos Rift. Science 213:1073-1083

Dando PR, Bussmann I, Niven SJ, O'Hara SCM, Schmaljohann R, Taylor LJ (1994) A methane seep area in the Skagerrak, the habitat of the pogonophore Siboglinum poseidoni and the bivalve mollusc Thyasira sarsi. Mar Ecol Prog Ser 107:157-167

Davis AR, Roberts DE, Cummins SP (1997) Rapid invasion of a sponge-dominated deep-reef by Caulerpa scalpelliformis (Chlorophyta) in Botany Bay, New South Wales. Aust J Ecol 22 (2): $146-150$

Dawes CJ, Hanisak D, Kenworthy WJ (1995) Seagrass biodiversity in the Indian river lagoon. Bull Mar Sci 57(1): $59-66$

Delaney JR, Robigou V, McDuff RE, Tivey MK (1992) Detailed geologic relationships of a vigorous hydrothermal system: the Endeavour vent field, northern Juan de Fuca Ridge. J Geophys Res 97:19663-19682

Desbruyères D, Laubier L (1991) Systematics, phylogeny, ecology and distribution of the Alvinellidae (Polychaeta) from deep-sea hydrothermal vents. Ophelia (Suppl) 5:31-45

Emmel TC (1973) An introduction to ecology and population biology. W.W. Norton and Company Inc, New York

Felbeck H, Powell MA, Hand SC, Somero GN (1985) Metabolic adaptations of hydrothermal vent animals. Bull Biol Soc Wash 6:261-272

Frontier S, Pichod-Viale D (1991) Ecosystèmes: structure, fonctionnement, évolution. Masson, Paris

Fujita T, Ohta S (1990) Photographic observations of deep-sea infaunal ophiuroids in Suruga Bay, Central Japan: an application of a free-fall system of time-lapse cameras and current metres. J Oceanogr Soc Japan 46(5):230-236

Fustec A, Desbruyères D, Laubier L (1988) Estimation de la biomasse des peuplements associés aux sources hydrothermales profondes de la dorsale du Pacifique oriental, à $13^{\circ} \mathrm{N}$. Oceanol Acta No sp 8:15-21 
Gage JD, Tyler PA (1991) Deep-sea biology: a natural history of organisms at the deep-sea floor. Cambridge University Press, Cambridge

Gambi MC, Lorenti M, Russo GF, Scipione MB (1.994) Benthic associations of the shallow hard bottoms off Terra Nova Bay, Ross sea: Zonation, biomass and population structure. Antarctic Sci 6(4):449-462

Grassle JF (1985) Hydrothermal vent animals: distribution and biology. Science 229:713-717

Grehan AJ, Juniper SK (1996) Clam distribution and subsurface hydrothermal processes at Chowder Hill (Middle Valley), Juan de Fuca Ridge. Mar Ecol Prog Ser 130:105-115

Gulliksen B (1984) Under-ice fauna from Svalbord waters. Sarsia 69 (1): 17-23

Hannington MD, Jonasson IR, Herzig PM, Petersen S (1995) Physical and chemical processes of seafloor mineralization at mid-ocean ridges. In: Humphris SE, Zierenberg RA, Mullineaux LS, Thomson RE (eds) Seafloor hydrothermal systems: physical, chemical, biological, and geological interactions. Geophys Monogr Ser 91, Washington, DC, p $115-157$

Hashimoto J, Ohta S, Tanaka T, Hotta H, Matsuzawa S, Sakai $\mathrm{H}$ (1989) Deep-sea assemblages dominated by the giant clam, Calyptogena soyoze, along the slope foot of Hatsushima Island, Sagami Bay, central Japan. Palaeogeogr Palaeoclimatol Palaeoecol 71:179-192

Hessler RR, Smithey WM Jr (1983) The distribution and community structure of megafauna at the Galapagos Rift hydrothermal vents. In: Rona PA, Boström $\mathrm{K}$, Laubier $\mathrm{L}$, Smith KL Jr (eds) Hydrothermal processes at seafloor spreading centers. Plenum Publishing Company, New York, p 735-770

Hessler RR, Smithey WM, Boudrias MA, Keller CH, Lutz RA, Childress JJ (1988) Temporal changes in megafauna at the Rose Garden hydrothermal vent (Galapagos Rift; eastern tropical Pacific). Deep-Sea Res 35:1681-1709

Ingole BS, Ansari ZA, Parukelar AH (1992) Benthic fauna around Mauritius Island, southwest Indian Ocean. Indian J Mar Sci 21(4):268-273

Jannasch HW, Mottl MJ (1985) Geomicrobiology of deep-sea hydrothermal vents. Science 229:717-725

Jollivet D (1996) Specific and genetic diversity at deep-sea hydrothermal vents: an overview. Biodiv Conserv 5 $1619-1653$

Juniper SK (1994) Ecology and biogeochemistry of $p_{a r}$ alvinella sulfincola at northeast Pacific hydrothermal vents: review and comparison with Alvinella spp. of the east Pacific rise. In: Dauvin JC, Laubier L, Reish DJ (eds) Actes de la tème Conférence Internationale des Polychètes. Mém Mus Natnl Hist Nat 162:453-462

Juniper SK, Sarrazin J (1995) Interaction of vent biota and hydrothermal deposits: present evidence and future experimentation. In: Humphris SE, Zierenberg RA, Mullineaux LS, Thomson RE (eds) Seafloor hydrothermal systems: physical, chemical, biological, and geological interactions. Geophys Monogr Ser 91, Washington, DC, p $178-193$

Juniper SK, Tunnicliffe V, Desbruyères D (1990) RegionaIscale features of northeast Pacific, East Pacific Rise and Gulf of Aden vents. In: McMurray GR (ed) Gorda Ridge: a frontier area in the United States' exclusive economic zone. Springer-Verlag, New York, p 265-278

Juniper SK, Jonasson IR, Tunnicliffe V, Southward AJ (1992) Influence of a tube building polychaete on hydrothermal chimney mineralization. Geology 20:895-898

Juniper SK, Fisher $C$ and the shipboard scientific party of BioROPOS 94: Galley A, McArthur A, MacDonald I, San- taguida F, Sarrazin J, Scott KT, Tunnicliffe V, Urcuyo I, Williams T (1994) A biological observatory at Endeavour Segment, Juan de Fuca Ridge. InterRidge News. InterRidge: Office, Université Pierre et Marie Curie, France $3(2): 23-25$

Juniper SK, Fisher C, Delaney J (1996) Report on ROPOS submersible operations on the R/V Thomas G. Thompson cruise: 12-27 August 1996. InterRidge News. InterRidge Office, Université Pierre et Marie Curie, France 5(2):25-26

Keeton WT, Gould JL (1993) Biological science. W. W. Norton \& Company Inc, New York, p 1115-1153

Kendall MA (1994) Polychaete assemblages along a depth gradient in a Spitsbergen fjord. Mem Mus Natl Hist Nat Zool 162:463-470

Koch V, Wolff M (1996) The mangrove snail Thais kiosquiformis Duclos: a case of life history adaptation to an extreme environment. J Shellfish Res 15 (2):421-432

Lalumière R, Messier D, Fournier J-J, McRoy CP (1994) Eelgrass meadows in a low Arctic environment, the northeast coast of James Bay, Québec. Aquat Bot 47(3-4):303-315

Latypov YY (1993) Benthic assemblages of the coral reefs of the Kondao Islands in the south China sea. Russ J Mar Biol 19(5-6):310-318

Laubier L, Ohta S, Sibuet M (1986) Découverte de communautés animales profondes durant la campagne francojaponaise KAIKO de plongées dans les fosses de subduction autour du Japon. C R Acad Sci Paris, Ser III, 303: $25-29$

Loenne OJ, Gulliksen B (1990) Source, density and composition of sympagic fauna in the Barents Sea. Polar Res 10(1-2):289-294

Lohse DP (1993) The importance of secondary substratum in a rocky intertidal community. J Exp Mar Biol Ecol 166:1-17

Lutz RA, Kennish MJ (1993) Ecology of deep-sea hydrothermal vent assemblages: a review. Rev Geophys 31:211-242

Mannino A, Montagna PA (1997) Small-scale spatial variation of macrobenthic community structure. Estuaries 20(1): $159-173$

Martineu P, Juniper SK, Fisher CR, Massoth GJ (1997) Sulfide binding in the body fluids of hydrothermal vent Alvinellid polychaetes. Physiol Zool 70:578-588

Mattila J (1993) Long-term changes in the bottom fauna along the Finnish coast of the southern Bothnian sea. Aqua Fenn 23(2):143-152

Odum EP (1969) The strategy of ecosystem development Science 164:262-270

Olu K, Duperret A, Sibuet M, Foucher JP, Fiala-Medioni A (1996) Structure and distribution of cold seep assemblages along the Peruvian active margin: relationship to geological and fluid patterns. Mar Ecol Prog Ser 132:109-125

Opitz S (1996) Trophic interactions in Caribbean coral reefs International Center for Living Aquatic Resources Management Tech Rep 43, Manila, Philippines

Ohta S, Laubier L (1987) Deep biological assemblages in the subduction zone of Japan from bottom photographs taken during 'Nautile' dives in the Kaiko project. Earth Planet. Sci Lett 83:329-342

Paradis S, Jonasson IR, Le Cheminant GM, Watkinson DH (1988) Two zinc-rich chimneys from the plume site, southern Juan de Fuca. Can Mineral 26:637-654

Platell ME, Potter IC (1996) Influence of water depth, season habitat and estuary location on the macrobenthic fauna of a seasonally closed estuary. J Mar Biol Assoc UK 76(1) $1-21$

Raveendran TV, Wagh AB (1993) Variation in biofouling on different species of Indian timbers. Mahasagar 26(1) $27-31$ 
Richardson MD, Briggs KB, Bowles FA, Tietjen JH (1995) A depauperate benthic assemblage from the nutrient-poor sediments of the Puerto-Rico trench. Deep-Sea Res 42(3): 351-364

Robigou V, Delaney JR, Stakes DS (1993) Large massive sulfide deposits in a newly discovered active hydrothermal system, the High-Rise Field, Endeavour Segment, Juan de Fuca Ridge. Geophys Res Lett 20:1887-1890

Rosenberg R, Loo LO, Moeller P (1991) Hypoxia, salinity and temperature as structuring factors for marine benthic assemblages in a eutrophic area. Neth $\mathrm{J}$ Sea Res 30 $121-129$

Sarrazin J, Robigou V, Juniper SK, Delaney JR (1997) Biological and geological dynamics over four years on a high temperature sulfide structure at the Juan de Fuca Ridge hydrothermal observatory. Mar Ecol Prog Ser 153:5-24

Sarrazin J, Juniper SK, Massoth G, Legendre P (1999) Physical and chemical factors influencing species distributions on hydrothermal sulfide edifices of the Juan de Fuca Ridge, northeast Pacific. Mar Ecol Prog Ser (in press)

Segonzac M (1992) Les peuplements associés à l'hydrothermalisme océanique du Snake Pit (dorsale médioatlantique; $23^{\circ} \mathrm{N}, 3480 \mathrm{~m}$ ): composition et microdistribution de la mégafaune. C R Acad Sci Paris, Ser III, 314: $593-600$

Sfriso A, Marcomini A, Paroni B, Orio AA (1993) Species composition, biomass, and net primary production in shallow coastal waters: the Venice lagoon. Bioresour Technol $44(3): 235-250$

Shank TM, Fornari DJ, Von Damm KL, Lilley MD, Haymon RM, Lutz RA (1998) Temporal and spatial patterns of biological community development at nascent deep-sea hydrothermal vents ( $9^{\circ} 50^{\prime} \mathrm{N}$, East Pacific Rise). Deep-Sea Res 45(1-3):465-515

Shepherd K, Juniper SK (1997) ROPOS: creating a scientific tool from an industrial ROV. Mar Tech Sc J 31:48-54

Somero GN, Siebenaller JF, Hochachka PW (1983) Biochemical and physiological adaptations of deep-sea animals. In: Rowe GT (ed) The sea, Vol 8, Deep-sea biology. John Wiley, New York, p 261-330

Editorial responsibility: Otto Kinne (Editor)

Oldendorf/Luhe, Germany
Southward EC, Tunnicliffe V, Black M (1995) Revision of the species of Ridgeia from northeast Pacific hydrothermal vents, with a redescription of Ridgeia piscesae Jones (Pogonophora: Obturata=Vestimentifera). Can J Zool 73: 282-295

Tivey MK, Delaney JR (1986) Growth of large sulfide structures on the Endeavour segment of the Juan de Fuca Ridge. Earth Planet Sci Lett 77:303-317

Tsutsumi H (1995) Impact of fish net pen culture on the benthic environment of a cove in south Japan. Estuaries $18(1 \mathrm{~A}): 108-115$

Tunnicliffe $V(1990)$ Observations on the effects of sampling on hydrothermal vent habitat and fauna of Axial Seamount. Juan de Fuca Ridge. J Geophys Res 95:12961-12966

Tunnicliffe $V$ (1991) The biology of hydrothermal vents: ecology and evolution. Oceanogr Mar Biol Annu Rev 29: 319-407

Tunnicliffe V, Juniper SK (1990) Dynamic character of the hydrothermal vent habitat and the nature of sulphide chimney fauna. Prog Oceanogr 24:1-13

Tunnicliffe V, Juniper SK, de Burgh ME (1985) The hydrothermal vent community on Axial Seamount, Juan de Fuca Ridge. Bull Biol Soc Wash 6:453-464

Tunnicliffe V, Desbruyères D, Jollivet D, Laubier L (1993) Systematic and ecological characteristics of Paralvinella sulfincola Desbruyères and Laubier, a new polychaete (family Alvinellidae) from northeast Pacific hydrothermal vents. Can J Zool 71:286-297

Tunnicliffe V, Embley RW, Holden JF, Butterfield DA, Massoth G, Juniper SK (1997) Biological colonization of new hydrothermal vents following an eruption on Juan de Fuca Ridge. Deep-Sea Res 44:1627-1644

Vose FE, Bell SS (1994) Resident fishes and macrobenthos in mangrove-rimmed habitats: evaluation of habitat restoration by hydrologic modification. Estuaries 17(3):585-596

Zettler ML (1996) Successful establishment of the spionid polychaete Marenzelleria viridis (Verrill, 1873) in the Darss-Zingst estuary (southern Baltic) and its influence on the indigenous macrozoobenthos. Arch Fish Mar Res $43(3): 273-284$

Submitted: August 12, 1997; Accepted: January 7, 1999

Proofs received from author(s): August 9, 1999 